\title{
Kentsel Donatı Elemanlarının Kalite Değerlendirilmesi: Uşak, Cumhuriyet Mahallesi Örneği
}

\author{
H. Berk TÜRKER ${ }^{1 *}$ (D) Gülbeyaz SAKINMAZ 2 (D) \\ ORCID 1: 0000-0002-8995-3259 \\ ORCID 2: 0000-0003-1662-0792 \\ ${ }_{1,2}$ Uşak Üniversitesi, Mimarlık ve Tasarım Fakültesi, Şehir ve Bölge Planlama Bölümü, 64200, Uşak, Türkiye. \\ *e-mail: berk.turker@usak.edu.tr \\ Öz
}

Kentsel donatı elemanları, kentsel mekanların en önemli bileşenlerinden biri olup, kentlerin mekansal, sosyokültürel, ekolojik karakterine uygun, kullanıcının gereksinimlerine cevap verecek şekilde tasarlanmalıdır. Donatı elemanlarının tasarım kriterleri doğrultusunda tasarlanması ve mekâna entegre edilmesi, kentsel mekânın kalitesinin ve konforunun yükseltilmesini sağlar. Bu çalışmada Uşak kenti, Cumhuriyet Mahallesi'ndeki 28 adet park ve çocuk oyun bahçesinde yer alan donatı elemanlarının kalite değerlendirilmesinin yapılması amaçlanmıştır. Çalışmada incelenen yeşil alanların alan tasarımı, zemin kaplaması, oyun alanı elemanları, oturma birimleri, aydınlatma elemanları, üst örtü ögeleri, su ögesi, çöp kutusu, bitkisel ögeler, işaret ve bilgi levhaları, kondisyon aletleri, sınırlandırıcılar ve spor alanları belirlenen kriterler (fonksiyonellik, estetik, ergonomi, dayanıkılık, bakım ve çevreye uyum) doğrultusunda 3'lü Likert ölçeğinde puanlanarak (çok yetersiz (1), kısmen yeterli (2) ve çok yeterli (3)) mevcut durumu incelenmiştir. Araştırma sonucunda Uşak kenti Cumhuriyet Mahallesi'nin kentte en çok yeşil alan sayısına sahip mahalle olmasına rağmen yeşil alanlarda yer alan donatı elemanlarının kalitesinin yetersiz ve kent kimliğiyle uyumsuz olduğu tespit edilmiştir.

Anahtar Kelimeler: Donatı elemanları, kentsel donatı, yeşil alanlar, kalite, Uşak

\section{Evaluation of Quality of Urban Furniture: The Case of Cumhuriyet Neighborhood, Uşak-Turkey}

\begin{abstract}
Urban furniture is one of the most important components of urban spaces and should be designed to meet the needs of the user in accordance with the spatial, sociocultural, and ecological character of the cities. Designing the urban equipment in accordance with the design criteria and integrating them into the space increases the quality and comfort of the urban space. The aim of the study is to evaluate the quality levels of urban furniture in 28 parks and children's playgrounds in the Cumhuriyet district of Usak Province. Area design, floor covering, playground elements, seating units, lighting elements, pergolas, water features, rubbish bins, landscape design, signs, sports equipment, and sports fields of 28 parks and children's playgrounds in Usak Cumhuriyet neighborhood and were scored on a 3-point Likert scale (not at all (1), moderately (2) and extremely (3)) in line with the determined criteria (functionality, aesthetics, ergonomics, durability, maintenance and environmental compliance). Findings show that although the Cumhuriyet neighborhood of Usak province has the highest number of green areas in the city, it has been determined that the quality of the urban furniture in the green areas is insufficient and incompatible with the identity of the city.
\end{abstract}

Keywords: Reinforcement elements, urban equipment, green spaces, quality, Uşak

Citation/Atıf: Türker, H.B. and Sakınmaz, G. (2021). Kentsel donatı elemanlarının kalite değerlendirilmesi: Uşak, Cumhuriyet Mahallesi örneği. Journal of Architectural Sciences and Applications, 6 (2), 638-661.

DOI: https://doi.org/10.30785/mbud.973693 


\section{Giriş}

Kentsel mekân, doğal ve yapay sistemlerin oluşturduğu bir mimarlık eseridir (Hasol, 2008) ve birer fiziksel ortamlardır. İnceoğlu ve Aytuğ (2009) kentsel mekânı, dış mekânda bulunan yapıların ve diğer tüm öğelerin birbirleriyle olan etkileşimi ile oluşan mekân olarak tanımlamıştır. Kentsel mekânlar, içinde yaşayan bireylerin yaşam kaliteleri üzerinde etkilidir (Beyhan, Peker, Polat ve Şenol, 2013). Çünkü bir kentteki kentsel mekânların kalitesi kentsel yaşam kalitesini etkileyen önemli faktörlerden biridir. Kısak (2021) kentsel çevrenin kalitesinin yüksek olmasının kentsel yaşanabilirlik seviyesini ve bireylerin yaşam kalitesini artırdığını belirtmiştir. Hanifehnezhad'a (2019) göre ise fiziksel çevrenin kalitesi, beklenti ve ihtiyaç karşılama için uygun olması çevresel kaliteyi artırmaktadır. Kentte yaşayan bireylerin çevreden memnuniyet derecesi yaşam kalitelerini olumlu etkileyerek daha üretken ve verimli olmalarını sağlar. Bundan dolayı kentsel çevrenin planlanmasında kentte yaşayan bireylerin talep ve eğilimleri oldukça önemlidir (Gündüz, 2019). Dolayısıyla kent kullanıcılarının yaşam kalitesinin iyileştirilmesi için kentsel mekânlar kentin ekolojik, sosyo-kültürel, ekonomik yapısına uygun bütüncül planlama ve tasarım yaklaşımıyla ele alınmalıdır. Erdönmez ve Çelik (2016), kentsel mekanların fiziksel, toplumsal, sosyolojik ve psikolojik perspektifte incelenmesi gerektiğini belirtmişlerdir.

Kaplan, Bayraktar, Tekel, Çalgüner ve Yalçıner (2003) "kentsel mekânda fiziksel, sosyo-kültürel ve sosyo-ekonomik bağlamlarda çok boyutlu, kentsel detay irdeleme ve çözümlemelerini içeren ayrıntılı bir düzenleme yöntemi" olarak tanımladığı kentsel tasarım, kentsel mekânların şekillenmesini sağlar. Kentsel mekânların şekillenmesinde en önemli ögelerden biri de kentsel donatı elemanlarıdır. Kentsel mekânın dekorasyonunda önemli rol üstlenen donatı elemanları (Aykut, 1997) aynı zamanda birer peyzaj elemanlarıdır.

Donatı elemanları kullanıcılara hizmet eden araçlardır ve işlevselliği ile kullanım ve ihtiyaca yanıt verme arasında bağlantı bulunmaktadır. Donatı elemanlarının ergonomik özellikleri kullanımı artırmakta ve işlevselliği etkilemektedir (Bulut, Atabeyoğlu ve Yeşil, 2008). Donatı elemanlarının tasarlanması tasarım ilkeleri doğrultusunda yapılmalıdır. Donatı elemanlarının tasarım ilkeleri doğrultusunda uygun bir şekilde tasarlanması kentsel yaşam kalitesini ve kentsel konforun artmasına, kentsel mekanlarda daha orijinal, estetik değeri yüksek ve pratik tasarımların ortaya çıkmasını sağlar. Ayrıca donatı elemanlarının çevreye uyumlu olması kent kimliğine katkıda bulunur ve imgeselliği artırır (Külekçi ve Irmak, 2019). Donatı elemanlarının işlevsel amaçlarının yanı sıra kentsel peyzajın kalitesinin artıııması açısından da önemlidir (Bulut ve diğerleri, 2008). Çünkü donatı elemanları kentsel mekânın algılanabilirliğini artırarak kentsel peyzajın estetik değerini olumlu olarak etkiler.

Kentsel mekânların veya kamusal mekânların her birey tarafından eşit olarak kullanım hakkı bulunduğunu ve bu mekânların eşit kullanım hakkı dikkate alınarak ergonomik ve konforlu şekilde planlanması ve tasarlanması oldukça önemlidir. Mekân organizasyonunun sağlanmasında eşit kullanım, estetik ve ergonomi en temel bileşenlerdir (Çelikyay ve Karayılmazlar, 2016). Kentsel donatı elemanları, kent halkının talep ve eğilimleri doğrultusunda bu temel bileşenler dikkate alınarak kentsel mekânın özelliklerine uygun biçimde tasarlanması, kentsel mekânın kalitesinin artırılmasını sağlar. Kentsel mekânın kalitesini, kentsel mekânı şekillendiren öğelerin en önemlisi olan kentsel donatı elemanlarının kullanılabilirliği, algılanabilirliği ve sürdürülebilirliği belirler. Bu bağlamda kentsel mekânın kalitesinin artırıması için kentsel donatı elemanlarının fonksiyonellik, estetik, ergonomi, dayanıklılık, bakımlılık ve çevreye uyum kriterleri doğrultusunda tasarlanması önemlidir.

- Fonksiyonellik: Fonksiyonelliği Illhan ve Kasap (2018) “Herhangi bir ürünün beklenen fayda ve amaca uygun olmasıdır" olarak tanımlamış ve donatı elemanlarının kentsel mekânda üstlendiği görevle uyumlu olması gerektiğini belirtmiştir. Bayazıt'a (2018) göre donatı elemanları bulunduğu kentsel mekâna fonksiyonel ve estetik olarak uyumlu olan elemanlardır. Karayılmazlar (2017), Kentsel donatı elemanları için fonksiyonellik ve görselliğin önemli olduğuna dikkat çekmiştir. Bir donatı elemanı için fonksiyonellik önceliklidir. Kentsel donatının tasarımı fonksiyonel olmadığı taktirde mekân için sorun oluşturur (Aksu, 2012). Bundan dolayı Yıldııım'a (2004) göre donatı elemanlarının işlevsel olması için insanın ergonomik yapısına uygun olarak tasarlanmalıdır. 
- Estetik: Kentsel donatı elemanlarının ve bunların kullanım biçimleri kentsel estetiğin sağlanmasında önemli katkıları bulunmaktadır (Erdoğan, 2006). Kentsel mekânlarında estetik açıdan tatminkâr olması mekânsal yaşanabilirliği artııı. Donatı elemanının estetik olması ile algılanabilirliği arasında doğru orantı vardır ve görünebilirlik ve anlamlandırıması donatı elemanına biçim sağlar (Yıldırım, 2004). Kentsel donatı elemanlarının estetik özellikleri görsel zenginliğe katkıda bulunarak kent imajı üzerinde etkilidir (Karadeniz, 2019).

- Ergonomi: Ergonomide insanın fiziksel boyutlarına uygun olacak şekilde donatı elemanları vb. boyutları ve malzemeleri tasarlanır. Bundan dolayı mekânın iyi bir şekilde analiz edilmesi ve insanların ergonomik yapısına uygun tasarımların yapılması önemli bir konudur (Akpınar Külekçi, 2018a). Kentsel mekânların ya da kamusal alanların estetik ve ergonomik olarak tasarlanmaması kullanıcıların mekân kullanımları üzerinde etkilidir (Karayılmazlar, 2017).

- Dayanıklıık: Kentsel donatı elemanları sürekli olarak rüzgâr, nem, güneş vb. dış etmenlere maruz kaldığı için donatı elemanlarının malzeme seçimi kritik öneme sahiptir. Kentsel donatı elemanlarının dış etmenlere karşı dayanıklı olması malzeme seçimi ve mekân içerisinde konumlandırmanın doğru yapılması önemlidir. Seçilen malzemenin dayanıklılık ve denemelerden geçmiş, kurumlarca tescil edilmesi o ürünün dayanıkııı̆ı ve kalitesinin güvenilir olduğunu göstermektedir (Perçin, 2021). Kentsel donatı elemanlarının sürekliliğinin sağlanması için belirli dönemlerde bakım çalışmalarının yapılması gerekmektedir. Yıldırım (2004), bakım çalışmalarında donatı elemanlarının insan sağlı̆ının ve konforu açısından uygunluğu kontrol edilmelidir.

- Çevreye Uyum: Donatı elemanları, mekânın ve kent kimliği arasında uyumun sağlamasında önemli etkenlerdendir (Karadeniz, 2019). Kent kimliğini oluşturan en önemli ögelerden biri donatı elemanlarıdır. Donatı elemanları tasarım ürünü olarak ele alınmalı ve bulunduğu kentsel mekân ile uyumlu bir şekilde organize edilmelidir (ilhan ve Kasap, 2018).

- Çevreye uyum ya da görsel uyum; donatı elemanlarının biçim ya da form, doku, renk ve deseni kentsel mekân ve diğer ögeleri ile uyumlu ve denge içerisinde olmasıdır. Kentsel donatı elemanlarının mekanla ile uyumsuzluğu mekânın kalitesini ve kullanıcılarını olumsuz yönde etkiler. Donatı elemanlarının ölçü, biçim, renk vb. açısından kentsel mekân ile dengeli, konforlu ve ergonomik olması kentsel mekandaki kullanılabilirliği artıır (ilhan ve Kasap, 2018).

Literatürde kentsel donatı elemanlarıyla ilgili çok sayıda çalışma bulunmaktadır. Külekçi ve Irmak (2019) araştırmasında Erzurum kentindeki bazı parklardaki donatı elemanlarının ergonomi, güvenlik, bakım, estetik, orijinallik, çevreye uyumluluk ve dayanıklılık kriterleri doğrultusunda kullanıcı görüşlerini incelemişlerdir. Yeşil ve Beyli (2018) çalışmasında, Ordu kentindeki kıyı parklarında yer alan donatı elemanlarının ergonomi, estetik, işlevsellik, iklime uygunluk, dayanıklılık, gece kullanımı kriterlerini uzman görüşleri doğrultusunda $5^{\prime} \mid$ li likert ölçeği ile puanlayarak incelemişlerdir. Karahan ve Sezen (2019), Erzurum kentinde bazı parkların peyzaj kalite göstergelerini değerlendirmişlerdir. Araştırmalarında 20 kişilik uzman grup tarafından görsel etki, yapısal tasarım, bitkisel tasarım, döşeme kalitesi kriterleri açısından 5'li likert ölçeği ile incelemişlerdir.

Çelikyay ve Karayılmazlar (2016) çalışmasında, Bartın kent merkezindeki kamusal alanlardaki donatı elemanlarını ergonomik ve estetik açıdan puanlayarak irdelemişlerdir ve kent kimliğiyle olan ilişkisi ortaya konulmuştur. Yıldırım ve diğerleri (2014), Antalya kentindeki bazı parklarda bulunan donatı elemanlarını kullanıcıların görüşleri ve uzman grup tarafından incelemişlerdir. Tekirdağ kenti Çorlu ilçesinde seçilen parklar, büyüklük, erişilebilirlik, alan kullanımları, yapısal ve bitkisel tasarım ilkeleri doğrultusunda incelenerek, $3^{\prime}$ lü likert ölçeğiyle değerlendirilmiştir.

Bu çalışma kapsamında yapılan araştırmalarda Uşak kentinde yer alan yeşil alanlarda donatı elemanları ile ilgili herhangi bir çalışmaya rastlanmamıştır. Bu çalışma literatürdeki bu boşluğu doldurmayı amaçlamıştır. Bundan dolayı bu çalışmada Uşak kentindeki mahalle düzeyinde parklarda yer alan donatı elemanlarının kalitesi ortaya konulmuştur. Araştırmada Uşak kent merkezi Cumhuriyet Mahalle'sindeki yeşil alanlarında yer alan donatı elemanları fonksiyonellik, estetik, ergonomi, dayanıkılık, bakımlılık ve çevreye uyum kriterleri açısından incelemiştir. 


\section{Materyal ve Yöntem}

Araştırmanın ana materyalini Uşak kent merkezinde yer alan Cumhuriyet Mahallesi sınırları içerisindeki 28 yeşil alan oluşturmaktadır (Şekil 1). Araştırma alanının yüz ölçümü $5786601,8 \mathrm{~m}^{2 \prime}$ dir. Uşak Ege bölgesinin iç batı kısmında yer almaktadır ve $38^{\circ} 13^{\prime \prime}$ ve $38^{\circ} 56^{\prime \prime}$ enlem ve $28^{\circ} 48^{\prime \prime}$ ve $29^{\circ} 57^{\prime \prime}$ boylam koordinatlarına sahiptir. Uşak kentinin kuzeyinde Kütahya, doğusunda Afyon, güneyinde Denizli ve batısında Manisa illeri yer almaktadır (Uşak Belediyesi, 2021). Uşak ilinin toplam nüfusu 369,433'tür (TUIK, 2021).

Uşak kent merkezi toplam 29 mahalleden oluşmaktadır. Uşak kent merkezinin nüfusu 228,871 ve toplam çocuk sayısı (0-17 yaş) 55,914'tür. Uşak kent merkezinde en yüksek nüfus yoğunluğu $(38,413)$ ve çocuk sayısına sahip mahallesi (9905) Kemal Öz Mahallesi'dir. Araştırma alanı olan Cumhuriyet Mahallesi ise ikinci en kalabalık nüfusa $(32,156$ kişi) ve çocuk sayısına sahip mahalledir $(55,914)$.

Uşak kent merkezinde kişi başına düşen aktif yeşil alan miktarı $8,50 \mathrm{~m}^{2} / \mathrm{kişi}$, çocuk başına düşen çocuk oyun alan miktarı ise $3.37 \mathrm{~m}^{2} /$ çocuk olarak hesaplanmıştır. Araştırma alanının (Cumhuriyet Mah.) kişi başına düşen yeşil alan miktarı $2.51 \mathrm{~m}^{2} /$ kişi'dir (Şekil 1).

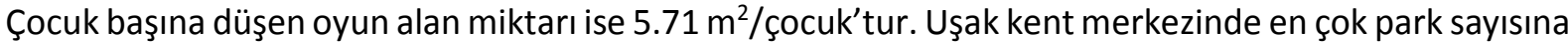
sahip mahallelerden birisi Cumhuriyet Mahallesi'dir ( 9 adet) ve kentte en çok çocuk oyun bahçesi Cumhuriyet Mahallesi'nde bulunmaktadır (21 adet). Bundan dolayı Cumhuriyet Mahallesi, sahip olduğu aktif yeşil alan miktarından dolayı Uşak kentinde çalışma alanı olarak belirlenmiştir.
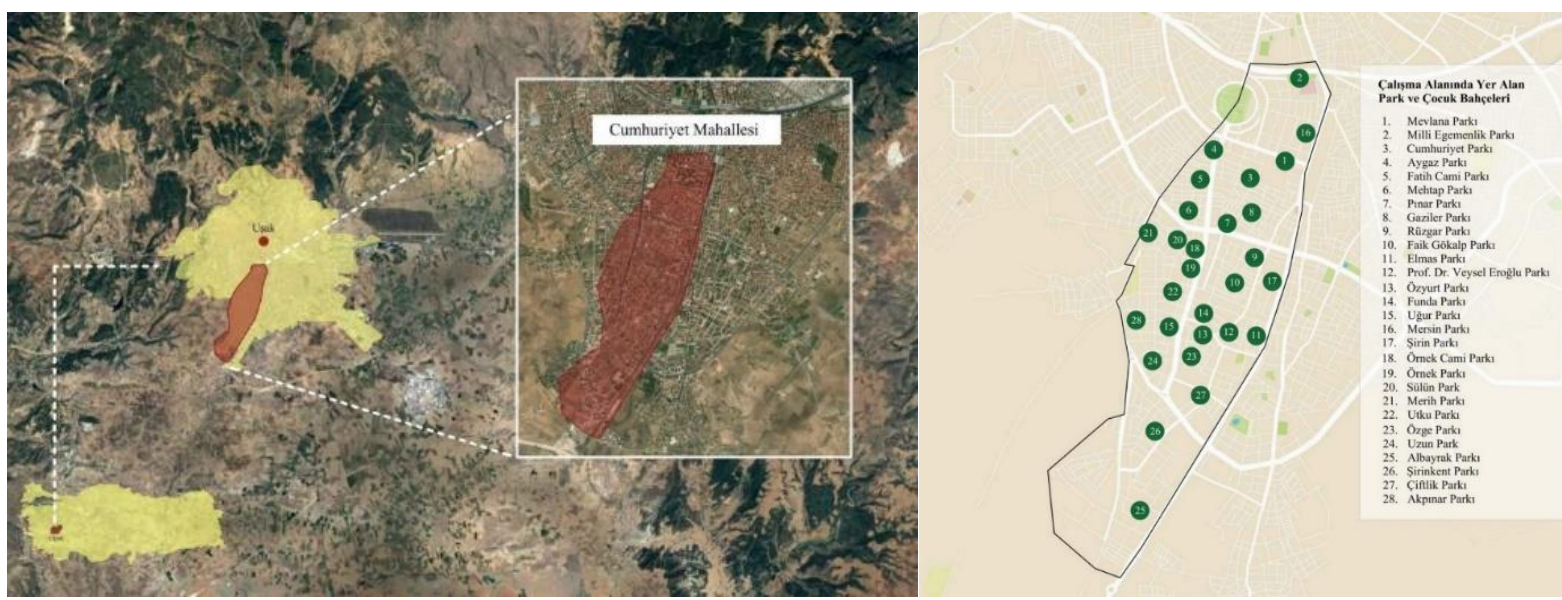

Şekil 1. Çalışma alanının konumu ve çalışma alanında yer alan yeşil alanların konumları

\subsection{Yöntem}

Çalışmada Cumhuriyet Mahallesi'ndeki yeşil alanlarda yer alan donatı elemanlarının belirlenen kriterler doğrultusunda değerlendirilmesi amaçlanmıştır. Çalışmada araştırma alanı içerisinde 28 park ve çocuk oyun bahçesi alan tasarımı ve içerisinde yer alan donatı elemanları; zemin kaplaması, oyun alanı elemanları, oturma birimleri, aydınlatma elemanları, üst örtü ögeleri, su ögesi, çöp kutusu, bitkisel ögeler, işaret ve bilgi levhaları, kondisyon aletleri, sınırlandırıcılar ve spor alanları belirlenen kriterler (fonksiyonellik, estetik, ergonomi, dayanıklılık, bakım ve çevreye uyum) doğrultusunda 3'lü Likert Ölçeği'nde puanlanarak (yetersiz (1), kısmen yeterli (2) ve yeterli (3)) Uşak kenti Cumhuriyet Mahallesi'nde yer alan donatı elemanlarının kaliteleri ortaya konulmuştur.

Araştırmanın 4 temel yöntem aşaması bulunmaktadır (Literatür taraması, veri toplama, analiz ve sentez). Araştırmanın ilk aşamasında yerli ve yabancı literatür araştırılmıştır. íkinci aşamada literatürde yer alan araştırmalardan yararlanılarak yeşil alanlardaki donatı elemanları ve kalite kriterleri belirlenerek arazi gözlem formu oluşturulmuştur.

Çalışma alanı 15.04.2021 - 25.04.2021 tarihleri arasında ziyaret edilerek arazi çalışması yapılmıştır. Arazi çalışmasından önce çalışma alanında bir ön arazi çalışması gerçekleştirilmiştir. 


\section{Bulgular}

Çalışmada yeşil alanlarda yer alan donatı elemanları fonksiyonellik, estetik, ergonomi, dayanıklılık, bakım ve çevreye uyum doğrultusunda incelenmiştir. Çizelge 1 'de donatı elemanlarının kalite puanlaması verilmiştir. Bu sonuçlara göre:

Park ve çocuk bahçelerinin fonksiyonellik, estetik, ergonomi, dayanıklılık, bakım ve çevreye uyum kriterleri doğrultusunda toplam puanı en yüksek olan yeşil alanlar; Şirinkent Parkı (176 p), Uğur Parkı (170 p) ve Rüzgâr Parkı'dır (131 p). Toplam puanı en düşük olan ise Fatih Cami Parkı'dır (43 p).

Incelenen yeşil alanların \%53,5'i toplam aritmetik ortalama puanının (97.57 p) üstündedir. Toplam aritmetik ortalamanın puanının üstünde olan yeşil alanlar şunlardır: Mevlâna Parkı (122 p), Milli Egemenlik Parkı (110 p), Aygaz Parkı (114 p), Rüzgar Parkı (139 p), Faik Gökalp Parkı (107 p), Elmas Parkı (106 p), Prof. Dr. Veysel Eroğlu Parkı (118 p), Funda Parkı (115 p), Uğur Parkı (170 p), Örnek Cami Parkı (105 p), Merih Parkı (124 p), Özge Parkı (131 p), Albayrak Parkı (108 p), Şirinkent Parkı (176 p), Akpınar Parkı (122 p).

Fonksiyonellik, estetik, ergonomi ve çevreye uyum kriterlerinde en yüksek puanı Şirinkent Parkı almıştır. Şirinkent Parkı'nın fonksiyonellik puanı 37, estetik puanı 22, ergonomi puanı 30 ve çevreye uyum puanı ise 32 'dir. Dayanıkııık ve bakım kriterlerinde en yüksek puanı alan yeşil alan Uğur Parkı'dır. Uğur Parkı'nın dayanıklılık puanı 28 ve bakım puanı $29^{\prime}$ dur. En düşük fonksiyonellik puanı ise Fatih Cami Parkı (9 p) ve Pınar Park (9 p), en düşük estetik puanı Mehtap Parkı (6 p), en düşük ergonomi ve dayanıklılık puanı alan Fatih Cami Parkı, en düşük bakım puanı Fatih Cami Parkı (6 p) ve Mehtap Parkı (6 p), en düşük çevreye uyum puanı ise Fatih Cami Parkı (6 puan) ve Özyurt Parkı (6 p) almıştır (Çizelge $1)$.

Çizelge 1. Donatı elemanlarının kalite puanlaması

\begin{tabular}{|c|c|c|c|c|c|c|c|c|c|}
\hline 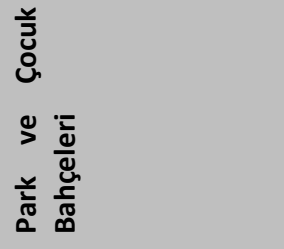 & 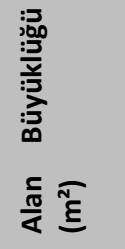 & 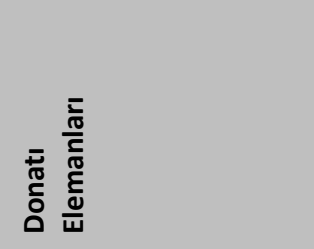 & 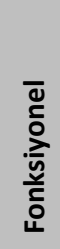 & $\begin{array}{l}\text { 羔 } \\
\text { 苞 }\end{array}$ & 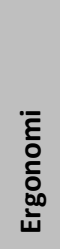 & $\begin{array}{l}\text { 兰 } \\
\text { 蒿 } \\
\text { 离 } \\
\text { 吾 }\end{array}$ & 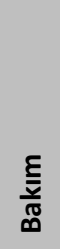 & 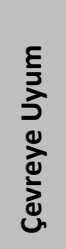 & $\begin{array}{l}\sum_{\leq} \\
0 \\
0\end{array}$ \\
\hline \multirow[t]{14}{*}{ Mevlana Parkı } & 6175,56 & Alanın Tasarımı & 3 & 2 & 2 & & & 3 & 10 \\
\hline & & Zemin Kaplaması & 3 & 2 & 2 & 2 & 2 & 3 & 14 \\
\hline & & Oyun Alanı Elemanı & 2 & 1 & 2 & 2 & 3 & 3 & 13 \\
\hline & & Oturma Birimleri & - & - & - & - & - & - & - \\
\hline & & Aydınlatma Elemanları & 3 & 3 & 2 & 3 & 3 & 2 & 16 \\
\hline & & Üst Örtü Ögeleri & 3 & 2 & 2 & 3 & 3 & 2 & 15 \\
\hline & & Su Ögesi & - & - & - & - & - & - & - \\
\hline & & Çöp Kutusu & 2 & 1 & 1 & 2 & 1 & 1 & 8 \\
\hline & & Bitkisel Ögeler & 2 & 1 & 2 & 2 & 2 & 2 & 11 \\
\hline & & Kondisyon Aletleri & 2 & 1 & 2 & 2 & 2 & 1 & 10 \\
\hline & & İşaret ve Bilgi Levhaları & 1 & 1 & 2 & 2 & 3 & 2 & 11 \\
\hline & & Sınırlandırıcılar & 3 & 2 & 2 & 2 & 3 & 2 & 14 \\
\hline & & Spor Alanları & - & - & - & - & - & - & - \\
\hline & & Toplam puan & 24 & 16 & 19 & 20 & 22 & 21 & 122 \\
\hline \multirow[t]{6}{*}{ Milli Egemenlik Parkı } & 8301 & Alanın Tasarımı & 3 & 2 & 2 & & & 2 & 9 \\
\hline & & Zemin Kaplaması & 3 & 1 & 2 & 2 & 3 & 3 & 14 \\
\hline & & Oyun Alanı Elemanı & 2 & 2 & 2 & 3 & 3 & 2 & 14 \\
\hline & & Oturma Birimleri & 3 & 1 & 2 & 2 & 2 & 1 & 11 \\
\hline & & Aydınlatma Elemanları & 3 & 1 & 2 & 3 & 3 & 2 & 13 \\
\hline & & Üst Örtü Ögeleri & 3 & 2 & 3 & 3 & 3 & 2 & 16 \\
\hline
\end{tabular}


Journal of Architectural Sciences and Applications, 2021, 6 (2), 638-661.

\begin{tabular}{|c|c|c|c|c|c|c|c|c|c|}
\hline & & Su Ögesi & 1 & 1 & 1 & 2 & 1 & 1 & 7 \\
\hline & & Çöp kutusu & - & - & - & - & - & - & - \\
\hline & & Bitkisel Ögeler & 1 & 1 & 2 & 2 & 2 & 1 & 9 \\
\hline & & Kondisyon Aletleri & - & - & - & - & - & - & - \\
\hline & & İşaret ve Bilgi Levhaları & 2 & 1 & 1 & 1 & 1 & 1 & 7 \\
\hline & & Sınırlandırıcılar & 3 & 1 & 2 & 1 & 2 & 1 & 10 \\
\hline & & Spor Alanları & - & - & - & - & - & - & - \\
\hline & & Toplam puan & 24 & 13 & 19 & 19 & 20 & 16 & 110 \\
\hline \multirow[t]{14}{*}{ Cumhuriyet Parkı } & 2124,43 & Alanın Tasarımı & 3 & 1 & 2 & & & 2 & 8 \\
\hline & & Zemin Kaplaması & 2 & 1 & 1 & 2 & 1 & 1 & 8 \\
\hline & & Oyun Alanı Elemanı & 3 & 1 & 2 & 3 & 3 & 2 & 14 \\
\hline & & Oturma Birimleri & 2 & 2 & 2 & 1 & 1 & 2 & 10 \\
\hline & & Aydınlatma Elemanları & 2 & 1 & 2 & 2 & 2 & 1 & 10 \\
\hline & & Üst Örtü Ögeleri & 3 & 1 & 1 & 2 & 1 & 1 & 9 \\
\hline & & Su Ögesi & - & - & - & - & - & - & - \\
\hline & & Çöp kutusu & 2 & 1 & 2 & 1 & 1 & 1 & 8 \\
\hline & & Bitkisel Ögeler & 2 & 1 & 1 & 2 & 1 & 1 & 8 \\
\hline & & Kondisyon Aletleri & - & - & - & - & - & - & - \\
\hline & & İşaret ve Bilgi Levhaları & - & - & - & - & - & - & - \\
\hline & & Sınırlandırıcılar & 2 & 1 & 2 & 2 & 3 & 2 & 12 \\
\hline & & Spor Alanları & - & - & - & - & - & - & - \\
\hline & & Toplam puan & 21 & 10 & 15 & 15 & 13 & 13 & 87 \\
\hline \multirow[t]{14}{*}{ Aygaz Parkı } & 1581,1 & Alanın Tasarımı & 3 & 2 & 2 & & & 3 & 10 \\
\hline & & Zemin Kaplaması & 3 & 2 & 3 & 3 & 3 & 3 & 17 \\
\hline & & Oyun Alanı Elemanı & 3 & 2 & 3 & 3 & 3 & 3 & 17 \\
\hline & & Oturma Birimleri & 3 & 2 & 3 & 3 & 3 & 3 & 17 \\
\hline & & Aydınlatma Elemanları & 3 & 2 & 2 & 3 & 2 & 2 & 14 \\
\hline & & Üst Örtü Ögeleri & - & - & - & - & - & - & - \\
\hline & & Su Ögesi & 1 & 1 & 1 & 1 & 1 & 1 & 6 \\
\hline & & Çöp kutusu & 2 & 1 & 1 & 1 & 1 & 1 & 7 \\
\hline & & Bitkisel Ögeler & 2 & 1 & 2 & 2 & 2 & 2 & 11 \\
\hline & & Kondisyon Aletleri & - & - & - & - & - & - & - \\
\hline & & İşaret ve Bilgi Levhaları & - & - & - & - & - & - & - \\
\hline & & Sınırlandırıcılar & 3 & 2 & 3 & 3 & 2 & 2 & 15 \\
\hline & & Spor Alanları & - & - & - & - & - & - & - \\
\hline & & Toplam puan & 23 & 15 & 20 & 19 & 17 & 20 & 114 \\
\hline \multirow[t]{10}{*}{ Fatih Cami Parkı } & 1387,73 & Alanın Tasarımı & 1 & 1 & 2 & & & 1 & 5 \\
\hline & & Zemin Kaplaması & 1 & 1 & 1 & 1 & 1 & 1 & 6 \\
\hline & & Oyun Alanı Elemanı & 2 & 2 & 2 & 2 & 1 & 1 & 10 \\
\hline & & Oturma Birimleri & - & - & - & - & - & - & - \\
\hline & & Aydınlatma Elemanları & 2 & 1 & 1 & 2 & 2 & 1 & 9 \\
\hline & & Üst Örtü Ögeleri & - & - & - & - & - & - & - \\
\hline & & Su Ögesi & - & - & - & - & - & - & - \\
\hline & & Çöp kutusu & - & - & - & - & - & - & - \\
\hline & & Bitkisel Ögeler & 1 & 1 & 1 & 1 & 1 & 1 & 6 \\
\hline & & Kondisyon Aletleri & - & - & - & - & - & - & - \\
\hline
\end{tabular}


Journal of Architectural Sciences and Applications, 2021, 6 (2), 638-661.

\begin{tabular}{|c|c|c|c|c|c|c|c|c|c|}
\hline & & İşaret ve Bilgi Levhaları & - & - & - & - & - & - & - \\
\hline & & Sınırlandırıcılar & 2 & 1 & 1 & 1 & 1 & 1 & 7 \\
\hline & & Spor Alanları & - & - & - & - & - & - & - \\
\hline & & Toplam puan & 9 & 7 & 8 & 7 & 6 & 6 & 43 \\
\hline \multirow[t]{14}{*}{ Mehtap Park } & 1077,56 & Alanın Tasarımı & 3 & 1 & 2 & & & 1 & 7 \\
\hline & & Zemin Kaplaması & 2 & 1 & 1 & 2 & 1 & 1 & 8 \\
\hline & & Oyun Alanı Elemanı & 3 & 2 & 2 & 2 & 2 & 2 & 13 \\
\hline & & Oturma Birimleri & - & - & - & - & - & - & - \\
\hline & & Aydınlatma Elemanları & - & - & - & - & - & - & - \\
\hline & & Üst Örtü Ögeleri & - & - & - & - & - & - & - \\
\hline & & Su Ögesi & - & - & - & - & - & - & - \\
\hline & & Çöp kutusu & - & - & - & - & - & - & - \\
\hline & & Bitkisel Ögeler & - & - & - & - & - & - & - \\
\hline & & Kondisyon Aletleri & - & - & - & - & - & - & - \\
\hline & & İşaret ve Bilgi Levhaları & 1 & 1 & 2 & 2 & 2 & 2 & 10 \\
\hline & & Sınırlandırıcılar & 2 & 1 & 2 & 2 & 1 & 1 & 9 \\
\hline & & Spor Alanları & - & - & - & - & - & - & - \\
\hline & & Toplam puan & 11 & 6 & 9 & 8 & 6 & 7 & 47 \\
\hline \multirow[t]{14}{*}{ Pınar Park } & 1582,27 & Alanın Tasarımı & 1 & 1 & 1 & & & 1 & 4 \\
\hline & & Zemin Kaplaması & 1 & 1 & 1 & 1 & 1 & 1 & 6 \\
\hline & & Oyun Alanı Elemanı & 2 & 2 & 2 & 2 & 2 & 2 & 12 \\
\hline & & Oturma Birimleri & - & - & - & - & - & - & - \\
\hline & & Aydınlatma Elemanları & - & - & - & - & - & - & - \\
\hline & & Üst Örtü Ögeleri & - & - & - & - & - & - & - \\
\hline & & Su Ögesi & - & - & - & - & - & - & - \\
\hline & & Çöp kutusu & - & - & - & - & - & - & - \\
\hline & & Bitkisel Ögeler & 1 & 1 & 1 & 2 & 2 & 1 & 8 \\
\hline & & Kondisyon Aletleri & 1 & 1 & 1 & 2 & 2 & 1 & 8 \\
\hline & & İşaret ve Bilgi Levhaları & 1 & 1 & 1 & 2 & 2 & 1 & 8 \\
\hline & & Sınırlandırıcılar & - & - & - & - & - & - & - \\
\hline & & Spor Alanları & 2 & 1 & 2 & 2 & 2 & 1 & 10 \\
\hline & & Toplam puan & 9 & 8 & 9 & 11 & 11 & 8 & 56 \\
\hline \multirow[t]{14}{*}{ Gaziler Parkı } & 1390,25 & Alanın Tasarımı & 3 & 1 & 2 & & & 2 & 8 \\
\hline & & Zemin Kaplaması & 2 & 1 & 1 & 2 & 1 & 1 & 8 \\
\hline & & Oyun Alanı Elemanı & 2 & 1 & 1 & 1 & 2 & 2 & 9 \\
\hline & & Oturma Birimleri & 1 & 1 & 1 & 1 & 1 & 1 & 6 \\
\hline & & Aydınlatma Elemanları & 2 & 1 & 1 & 2 & 2 & 1 & 9 \\
\hline & & Üst Örtü Ögeleri & - & - & - & - & - & - & - \\
\hline & & Su Ögesi & - & - & - & - & - & - & - \\
\hline & & Çöp kutusu & - & - & - & - & - & - & - \\
\hline & & Bitkisel Ögeler & 2 & 1 & 1 & 1 & 1 & 1 & 7 \\
\hline & & Kondisyon Aletleri & 3 & 1 & 2 & 2 & 2 & 2 & 12 \\
\hline & & İşaret ve Bilgi Levhaları & - & - & - & - & - & - & - \\
\hline & & Sınırlandırıcılar & 2 & 1 & 1 & 1 & 1 & 1 & 7 \\
\hline & & Spor Alanları & - & - & - & - & - & - & - \\
\hline & & Toplam puan & 17 & 8 & 10 & 10 & 10 & 11 & 66 \\
\hline
\end{tabular}


Journal of Architectural Sciences and Applications, 2021, 6 (2), 638-661.

\begin{tabular}{|c|c|c|c|c|c|c|c|c|c|}
\hline \multirow[t]{14}{*}{ Rüzgar Parkı } & \multirow[t]{14}{*}{2331,43} & Alanın Tasarımı & 3 & 3 & \multicolumn{3}{|l|}{3} & \multirow{2}{*}{$\frac{3}{2}$} & \multirow{2}{*}{$\begin{array}{l}12 \\
11\end{array}$} \\
\hline & & Zemin Kaplaması & 2 & 2 & 1 & 2 & 2 & & \\
\hline & & Oyun Alanı Elemanı & 3 & 3 & 3 & 3 & 3 & 3 & 18 \\
\hline & & Oturma Birimleri & 2 & 1 & 1 & 2 & 2 & 2 & 10 \\
\hline & & Aydınlatma Elemanları & 2 & 2 & 2 & 3 & 2 & 2 & 13 \\
\hline & & Üst Örtü Ögeleri & 3 & 2 & 2 & 2 & 2 & 2 & 13 \\
\hline & & Su Ögesi & - & - & - & - & - & - & - \\
\hline & & Çöp kutusu & - & - & - & - & - & - & - \\
\hline & & Bitkisel Ögeler & 2 & 1 & 2 & 1 & 1 & 1 & 8 \\
\hline & & Kondisyon Aletleri & 3 & 2 & 2 & 3 & 3 & 3 & 16 \\
\hline & & İşaret ve Bilgi Levhaları & 1 & 1 & 1 & 1 & 2 & 2 & 8 \\
\hline & & Sınırlandırıcılar & 3 & 2 & 2 & 3 & 3 & 3 & 16 \\
\hline & & Spor Alanları & 3 & 2 & 2 & 3 & 2 & 2 & 14 \\
\hline & & Toplam puan & 27 & 21 & 21 & 23 & 22 & 25 & 139 \\
\hline \multirow[t]{14}{*}{ Faik Gökalp Parkı } & \multirow[t]{14}{*}{3828,6} & Alanın Tasarımı & 3 & 1 & 2 & & & 2 & 8 \\
\hline & & Zemin Kaplaması & 2 & 1 & 1 & 2 & 2 & 2 & 10 \\
\hline & & Oyun Alanı Elemanı & 2 & 1 & 2 & 2 & 2 & 2 & 11 \\
\hline & & Oturma Birimleri & 3 & 2 & 2 & 3 & 3 & 2 & 15 \\
\hline & & Aydınlatma Elemanları & 3 & 2 & 2 & 2 & 2 & 1 & 12 \\
\hline & & Üst Örtü Ögeleri & - & - & - & - & - & - & - \\
\hline & & Su Ögesi & - & - & - & - & - & - & - \\
\hline & & Çöp kutusu & 3 & 1 & 2 & 1 & 1 & 1 & 9 \\
\hline & & Bitkisel Ögeler & 2 & 2 & 3 & 3 & 3 & 3 & 16 \\
\hline & & Kondisyon Aletleri & 3 & 1 & 2 & 2 & 2 & 1 & 11 \\
\hline & & İşaret ve Bilgi Levhaları & - & - & - & - & - & - & - \\
\hline & & Sınırlandırıcılar & 3 & 2 & 2 & 3 & 3 & 2 & 15 \\
\hline & & Spor Alanları & - & - & - & - & - & - & - \\
\hline & & Toplam puan & 24 & 13 & 18 & 18 & 18 & 16 & 107 \\
\hline \multirow[t]{14}{*}{ Elmas Parkı } & \multirow[t]{14}{*}{3157,39} & Alanın Tasarımı & 3 & 2 & 2 & & & 2 & 9 \\
\hline & & Zemin Kaplaması & 2 & 1 & 2 & 3 & 3 & 2 & 13 \\
\hline & & Oyun Alanı Elemanı & 2 & 2 & 2 & 3 & 3 & 2 & 14 \\
\hline & & Oturma Birimleri & 3 & 1 & 2 & 3 & 2 & 2 & 13 \\
\hline & & Aydınlatma Elemanları & 3 & 1 & 2 & 3 & 2 & 1 & 12 \\
\hline & & Üst Örtü Ögeleri & - & - & - & - & - & - & - \\
\hline & & Su Ögesi & - & - & - & - & - & - & - \\
\hline & & Çöp kutusu & - & - & - & - & - & - & - \\
\hline & & Bitkisel Ögeler & 2 & 1 & 2 & 2 & 1 & 2 & 10 \\
\hline & & Kondisyon Aletleri & 3 & 1 & 2 & 2 & 2 & 1 & 11 \\
\hline & & İşaret ve Bilgi Levhaları & 2 & 1 & 2 & 3 & 2 & 2 & 12 \\
\hline & & Sınırlandırıcılar & 3 & 1 & 2 & 2 & 2 & 2 & 12 \\
\hline & & Spor Alanları & - & - & - & - & - & - & - \\
\hline & & Toplam puan & 23 & 11 & 18 & 21 & 17 & 16 & 106 \\
\hline \multirow[t]{4}{*}{ Prof. Dr. Veysel Eroğlu Parkı } & \multirow[t]{4}{*}{3391,82} & Alanın Tasarımı & 3 & 2 & 3 & & & 3 & 11 \\
\hline & & Zemin Kaplaması & 3 & 3 & 2 & 3 & 3 & 3 & 17 \\
\hline & & Oyun Alanı Elemanı & 3 & 3 & 2 & 2 & 3 & 3 & 16 \\
\hline & & Oturma Birimleri & 2 & 2 & 2 & 3 & 3 & 3 & 15 \\
\hline
\end{tabular}


Journal of Architectural Sciences and Applications, 2021, 6 (2), 638-661.

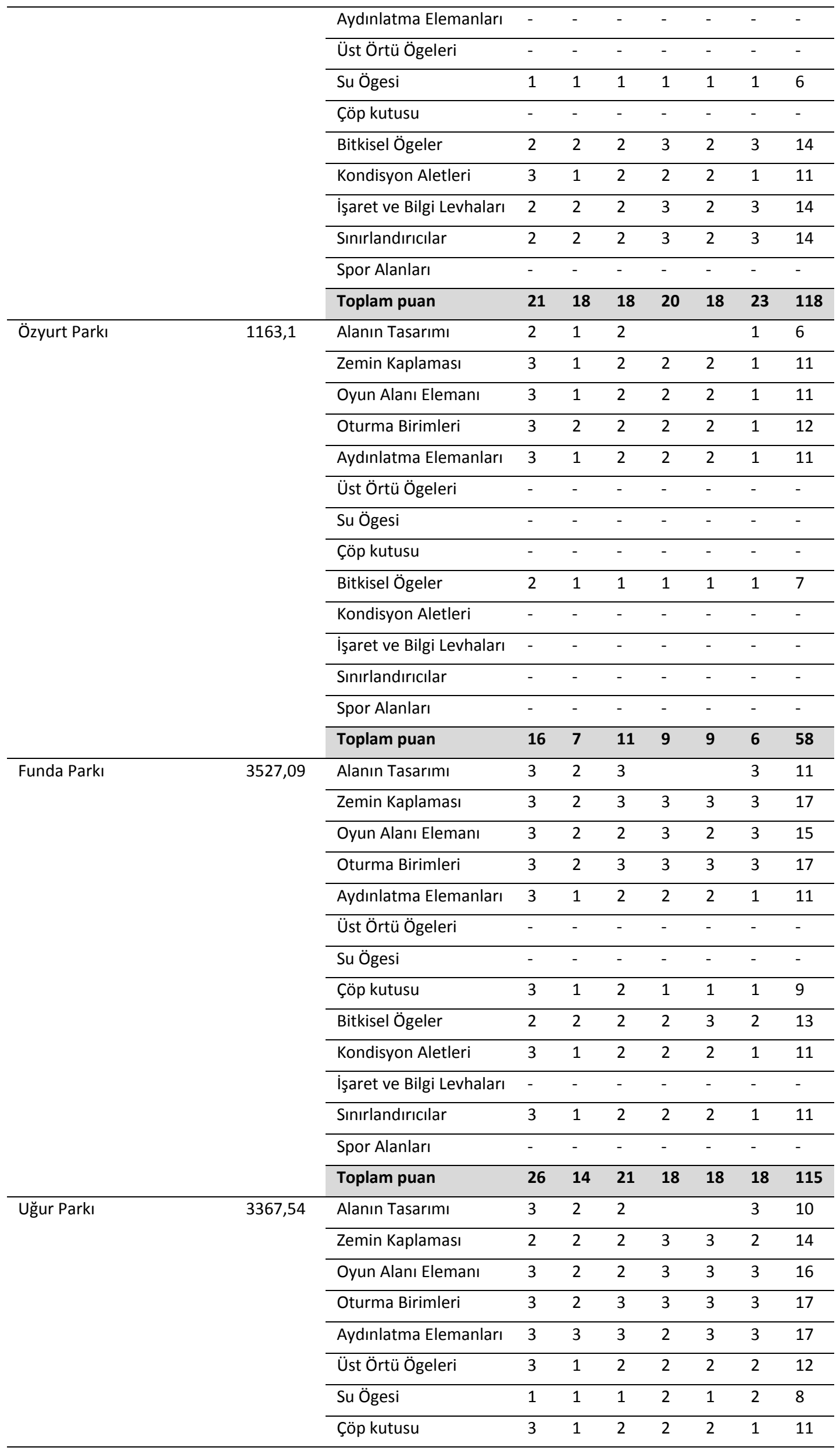


Journal of Architectural Sciences and Applications, 2021, 6 (2), 638-661.

\begin{tabular}{|c|c|c|c|c|c|c|c|c|c|}
\hline & & Bitkisel Ögeler & 2 & 2 & 3 & 2 & 3 & 3 & 15 \\
\hline & & Kondisyon Aletleri & 3 & 1 & 2 & 2 & 2 & 1 & 11 \\
\hline & & İşaret ve Bilgi Levhaları & 2 & 1 & 2 & 2 & 2 & 1 & 10 \\
\hline & & Sınırlandırıcılar & 3 & 2 & 3 & 3 & 3 & 3 & 17 \\
\hline & & Spor Alanları & 3 & 1 & 2 & 2 & 2 & 2 & 12 \\
\hline & & Toplam puan & 34 & 21 & 29 & 28 & 29 & 29 & 170 \\
\hline \multirow[t]{14}{*}{ Mersin Parkı } & 445,24 & Alanın Tasarımı & 1 & 1 & 1 & & & 1 & 4 \\
\hline & & Zemin Kaplaması & 2 & 1 & 1 & 1 & 1 & 2 & 8 \\
\hline & & Oyun Alanı Elemanı & 2 & 1 & 2 & 2 & 2 & 1 & 10 \\
\hline & & Oturma Birimleri & 1 & 1 & 1 & 1 & 1 & 1 & 6 \\
\hline & & Aydınlatma Elemanları & 2 & 1 & 2 & 2 & 2 & 2 & 11 \\
\hline & & Üst Örtü Ögeleri & - & - & - & - & - & - & - \\
\hline & & Su Ögesi & - & - & - & - & - & - & - \\
\hline & & Çöp kutusu & - & - & - & - & - & - & - \\
\hline & & Bitkisel Ögeler & 1 & 1 & 1 & 1 & 1 & 1 & 6 \\
\hline & & Kondisyon Aletleri & 3 & 1 & 2 & 2 & 2 & 1 & 11 \\
\hline & & İşaret ve Bilgi Levhaları & - & - & - & - & - & - & - \\
\hline & & Sınırlandırıcılar & 1 & 1 & 2 & 2 & 1 & 1 & 8 \\
\hline & & Spor Alanları & - & - & - & - & - & - & - \\
\hline & & Toplam puan & 13 & 8 & 12 & 11 & 10 & 10 & 64 \\
\hline \multirow[t]{14}{*}{ Şirin Park } & 1079,32 & Alanın Tasarımı & 2 & 1 & 1 & & & 1 & 5 \\
\hline & & Zemin Kaplaması & 2 & 1 & 2 & 2 & 2 & 2 & 11 \\
\hline & & Oyun Alanı Elemanı & 2 & 1 & 2 & 3 & 3 & 2 & 13 \\
\hline & & Oturma Birimleri & 3 & 2 & 2 & 3 & 3 & 2 & 15 \\
\hline & & Aydınlatma Elemanları & 3 & 1 & 2 & 2 & 2 & 1 & 11 \\
\hline & & Üst Örtü Ögeleri & - & - & - & - & - & - & - \\
\hline & & Su Ögesi & - & - & - & - & - & - & - \\
\hline & & Çöp kutusu & - & - & - & - & - & - & - \\
\hline & & Bitkisel Ögeler & - & - & - & - & - & - & - \\
\hline & & Kondisyon Aletleri & 3 & 1 & 2 & 2 & 1 & 1 & 10 \\
\hline & & İşaret ve Bilgi Levhaları & 2 & 1 & 1 & 2 & 2 & 1 & 9 \\
\hline & & Sınırlandırıcılar & - & - & - & - & - & - & - \\
\hline & & Spor Alanları & - & - & - & - & - & - & - \\
\hline & & Toplam puan & 17 & 8 & 12 & 14 & 13 & 10 & 74 \\
\hline \multirow[t]{12}{*}{ Örnek Cami Parkı } & 846,8 & Alanın Tasarımı & 3 & 2 & 3 & & & 2 & 10 \\
\hline & & Zemin Kaplaması & 2 & 1 & 1 & 1 & 1 & 1 & 7 \\
\hline & & Oyun Alanı Elemanı & 3 & 3 & 3 & 3 & 3 & 3 & 18 \\
\hline & & Oturma Birimleri & 3 & 1 & 2 & 2 & 2 & 2 & 12 \\
\hline & & Aydınlatma Elemanları & 3 & 2 & 2 & 3 & 2 & 1 & 13 \\
\hline & & Üst Örtü Ögeleri & - & - & - & - & - & - & - \\
\hline & & Su Ögesi & - & - & - & - & - & - & - \\
\hline & & Çöp kutusu & - & - & - & - & - & - & - \\
\hline & & Bitkisel Ögeler & 1 & 1 & 1 & 1 & 1 & 1 & 6 \\
\hline & & Kondisyon Aletleri & 3 & 1 & 2 & 2 & 2 & 1 & 11 \\
\hline & & İşaret ve Bilgi Levhaları & 2 & 2 & 2 & 2 & 2 & 1 & 11 \\
\hline & & Sınırlandırıcılar & 3 & 2 & 3 & 3 & 3 & 3 & 17 \\
\hline
\end{tabular}


Journal of Architectural Sciences and Applications, 2021, 6 (2), 638-661.

\begin{tabular}{|c|c|c|c|c|c|c|c|c|c|}
\hline & & Spor Alanları & - & - & - & - & - & - & - \\
\hline & & Toplam puan & 23 & 15 & 19 & 17 & 16 & 15 & 105 \\
\hline \multirow[t]{14}{*}{ Örnek Parkı } & \multirow[t]{14}{*}{811,56} & Alanın Tasarımı & 2 & 1 & 2 & & & 1 & 6 \\
\hline & & Zemin Kaplaması & 1 & 1 & 1 & 1 & 1 & 1 & 6 \\
\hline & & Oyun Alanı Elemanı & 2 & 1 & 2 & 2 & 2 & 1 & 10 \\
\hline & & Oturma Birimleri & 3 & 1 & 2 & 2 & 2 & 1 & 11 \\
\hline & & Aydınlatma Elemanları & - & - & - & - & - & - & - \\
\hline & & Üst Örtü Ögeleri & - & - & - & - & - & - & - \\
\hline & & Su Ögesi & - & - & - & - & - & - & - \\
\hline & & Çöp kutusu & - & - & - & - & - & - & - \\
\hline & & Bitkisel Ögeler & 1 & 1 & 1 & 1 & 1 & 1 & 6 \\
\hline & & Kondisyon Aletleri & 2 & 1 & 2 & 2 & 2 & 1 & 10 \\
\hline & & İşaret ve Bilgi Levhaları & - & - & - & - & - & - & - \\
\hline & & Sınırlandırıcılar & 2 & 1 & 2 & 2 & 2 & 2 & 11 \\
\hline & & Spor Alanları & - & - & - & - & - & - & - \\
\hline & & Toplam puan & 13 & 7 & 12 & 10 & 10 & 8 & 60 \\
\hline \multirow[t]{14}{*}{ Sülün Parkı } & \multirow[t]{14}{*}{922,81} & Alanın Tasarımı & 2 & 1 & 2 & & & 2 & 7 \\
\hline & & Zemin Kaplaması & 2 & 1 & 1 & 2 & 1 & 2 & 9 \\
\hline & & Oyun Alanı Elemanı & 2 & 2 & 2 & 2 & 2 & 2 & 12 \\
\hline & & Oturma Birimleri & 2 & 1 & 2 & 1 & 1 & 1 & 8 \\
\hline & & Aydınlatma Elemanları & - & - & - & - & - & - & - \\
\hline & & Üst Örtü Ögeleri & - & - & - & - & - & - & - \\
\hline & & Su Ögesi & - & - & - & - & - & - & - \\
\hline & & Çöp kutusu & - & - & - & - & - & - & - \\
\hline & & Bitkisel Ögeler & 1 & 1 & 1 & 2 & 1 & 1 & 7 \\
\hline & & Kondisyon Aletleri & 2 & 1 & 2 & 2 & 1 & 1 & 9 \\
\hline & & İşaret ve Bilgi Levhaları & - & - & - & - & - & - & - \\
\hline & & Sınırlandırıcılar & 2 & 1 & 2 & 2 & 2 & 2 & 11 \\
\hline & & Spor Alanları & - & - & - & - & - & - & - \\
\hline & & Toplam puan & 13 & 8 & 12 & 11 & 8 & 11 & 63 \\
\hline \multirow[t]{14}{*}{ Merih Parkı } & \multirow[t]{14}{*}{2416,37} & Alanın Tasarımı & 3 & 2 & 2 & & & 2 & 9 \\
\hline & & Zemin Kaplaması & 2 & 2 & 2 & 2 & 2 & 2 & 12 \\
\hline & & Oyun Alanı Elemanı & 3 & 3 & 3 & 3 & 3 & 3 & 18 \\
\hline & & Oturma Birimleri & 3 & 2 & 2 & 3 & 3 & 3 & 16 \\
\hline & & Aydınlatma Elemanları & 3 & 1 & 2 & 2 & 2 & 1 & 11 \\
\hline & & Üst Örtü Ögeleri & - & - & - & - & - & - & - \\
\hline & & Su Ögesi & - & - & - & - & - & - & - \\
\hline & & Çöp kutusu & 3 & 1 & 2 & 2 & 2 & 1 & 11 \\
\hline & & Bitkisel Ögeler & 1 & 1 & 1 & 2 & 1 & 1 & 6 \\
\hline & & Kondisyon Aletleri & 3 & 2 & 2 & 3 & 3 & 2 & 15 \\
\hline & & İşaret ve Bilgi Levhaları & 3 & 1 & 2 & 2 & 2 & 1 & 11 \\
\hline & & Sınırlandırıcılar & 3 & 2 & 3 & 3 & 2 & 2 & 15 \\
\hline & & Spor Alanları & - & - & - & - & - & - & - \\
\hline & & Toplam puan & 27 & 17 & 21 & 22 & 20 & 18 & 124 \\
\hline \multirow[t]{2}{*}{ Utku Parkı } & \multirow[t]{2}{*}{1239,52} & Alanın Tasarımı & 3 & 1 & 2 & & & 2 & 8 \\
\hline & & Zemin Kaplaması & 2 & 1 & 2 & 2 & 1 & 2 & 10 \\
\hline
\end{tabular}


Journal of Architectural Sciences and Applications, 2021, 6 (2), 638-661.

\begin{tabular}{|c|c|c|c|c|c|c|c|c|c|}
\hline & & Oyun Alanı Elemanı & 3 & 2 & 3 & 3 & 3 & 2 & 16 \\
\hline & & Oturma Birimleri & 3 & 2 & 2 & 2 & 2 & 2 & 13 \\
\hline & & Aydınlatma Elemanları & - & - & - & - & - & - & - \\
\hline & & Üst Örtü Ögeleri & - & - & - & - & - & - & - \\
\hline & & Su Ögesi & - & - & - & - & - & - & - \\
\hline & & Çöp kutusu & 3 & 1 & 2 & 2 & 1 & 1 & 10 \\
\hline & & Bitkisel Ögeler & 2 & 1 & 1 & 1 & 1 & 1 & 7 \\
\hline & & Kondisyon Aletleri & 3 & 1 & 2 & 2 & 2 & 1 & 11 \\
\hline & & İşaret ve Bilgi Levhaları & 3 & 1 & 1 & 1 & 1 & 1 & 8 \\
\hline & & Sınırlandırıcılar & 3 & 2 & 3 & 2 & 2 & 2 & 14 \\
\hline & & Spor Alanları & - & - & - & - & - & - & - \\
\hline & & Toplam puan & 25 & 12 & 18 & 15 & 13 & 14 & 97 \\
\hline \multirow[t]{14}{*}{ Özge Parkı } & 2420,68 & Alanın Tasarımı & 3 & 2 & 3 & & & 3 & 11 \\
\hline & & Zemin Kaplaması & 3 & 3 & 2 & 2 & 3 & 3 & 16 \\
\hline & & Oyun Alanı Elemanı & 3 & 2 & 3 & 3 & 3 & 3 & 17 \\
\hline & & Oturma Birimleri & 3 & 2 & 3 & 3 & 2 & 3 & 16 \\
\hline & & Aydınlatma Elemanları & 3 & 2 & 3 & 3 & 2 & 2 & 15 \\
\hline & & Üst Örtü Ögeleri & - & - & - & - & - & - & - \\
\hline & & Su Ögesi & - & - & - & - & - & - & - \\
\hline & & Çöp kutusu & - & - & - & - & - & - & - \\
\hline & & Bitkisel Ögeler & 2 & 1 & 1 & 1 & 1 & 1 & 7 \\
\hline & & Kondisyon Aletleri & 3 & 1 & 2 & 1 & 1 & 1 & 9 \\
\hline & & İşaret ve Bilgi Levhaları & 3 & 1 & 1 & 1 & 1 & 1 & 8 \\
\hline & & Sınırlandırıcılar & 2 & 2 & 3 & 3 & 3 & 3 & 16 \\
\hline & & Spor Alanları & 3 & 2 & 3 & 3 & 3 & 2 & 16 \\
\hline & & Toplam puan & 28 & 18 & 24 & 20 & 19 & 22 & 131 \\
\hline \multirow[t]{14}{*}{ Uzun Park } & 1252,57 & Alanın Tasarımı & 3 & 1 & 2 & & & 2 & 8 \\
\hline & & Zemin Kaplaması & 1 & 1 & 1 & 1 & 1 & 1 & 6 \\
\hline & & Oyun Alanı Elemanı & 3 & 1 & 2 & 2 & 2 & 2 & 12 \\
\hline & & Oturma Birimleri & 3 & 2 & 2 & 3 & 3 & 2 & 15 \\
\hline & & Aydınlatma Elemanları & 3 & 2 & 2 & 3 & 2 & 2 & 14 \\
\hline & & Üst Örtü Ögeleri & - & - & - & - & - & - & - \\
\hline & & Su Ögesi & - & - & - & - & - & - & - \\
\hline & & Çöp kutusu & - & - & - & - & - & - & - \\
\hline & & Bitkisel Ögeler & 1 & 1 & 1 & 1 & 1 & 1 & 6 \\
\hline & & Kondisyon Aletleri & 3 & 1 & 2 & 2 & 2 & 2 & 12 \\
\hline & & İşaret ve Bilgi Levhaları & - & - & - & - & - & - & - \\
\hline & & Sınırlandırıcılar & - & - & - & - & - & - & - \\
\hline & & Spor Alanları & 3 & 1 & 1 & 2 & 2 & 1 & 10 \\
\hline & & Toplam puan & 20 & 10 & 13 & 14 & 13 & 13 & 83 \\
\hline \multirow[t]{6}{*}{ Albayrak Parkı } & 3394,45 & Alanın Tasarımı & 3 & 1 & 2 & & & 2 & 8 \\
\hline & & Zemin Kaplaması & 3 & 1 & 2 & 2 & 2 & 1 & 11 \\
\hline & & Oyun Alanı Elemanı & 3 & 1 & 3 & 2 & 2 & 2 & 13 \\
\hline & & Oturma Birimleri & 3 & 1 & 2 & 2 & 2 & 2 & 12 \\
\hline & & Aydınlatma Elemanları & 3 & 1 & 2 & 2 & 2 & 1 & 11 \\
\hline & & Üst Örtü Ögeleri & - & - & - & - & - & - & - \\
\hline
\end{tabular}


Journal of Architectural Sciences and Applications, 2021, 6 (2), 638-661.

\begin{tabular}{|c|c|c|c|c|c|c|c|c|c|}
\hline & & Su Ögesi & - & - & - & - & - & - & - \\
\hline & & Çöp kutusu & - & - & - & - & - & - & - \\
\hline & & Bitkisel Ögeler & 2 & 1 & 1 & 1 & 1 & 1 & 7 \\
\hline & & Kondisyon Aletleri & 3 & 1 & 2 & 2 & 2 & 1 & 11 \\
\hline & & İşaret ve Bilgi Levhaları & 2 & 1 & 2 & 1 & 1 & 1 & 8 \\
\hline & & Sınırlandırıcılar & 3 & 1 & 2 & 2 & 2 & 2 & 12 \\
\hline & & Spor Alanları & 3 & 1 & 3 & 3 & 3 & 2 & 15 \\
\hline & & Toplam puan & 28 & 10 & 21 & 17 & 17 & 15 & 108 \\
\hline \multirow[t]{14}{*}{ Şirinkent Parkı } & 14144,67 & Alanın Tasarımı & 3 & 3 & 3 & & & 3 & 12 \\
\hline & & Zemin Kaplaması & 3 & 2 & 2 & 3 & 3 & 3 & 16 \\
\hline & & Oyun Alanı Elemanı & 3 & 2 & 2 & 2 & 2 & 2 & 13 \\
\hline & & Oturma Birimleri & 3 & 1 & 2 & 2 & 2 & 3 & 13 \\
\hline & & Aydınlatma Elemanları & 3 & 1 & 2 & 2 & 2 & 2 & 12 \\
\hline & & Üst Örtü Ögeleri & 3 & 2 & 3 & 3 & 3 & 3 & 17 \\
\hline & & Su Ögesi & 2 & 2 & 2 & 2 & 1 & 3 & 12 \\
\hline & & Çöp kutusu & 3 & 1 & 2 & 2 & 2 & 2 & 12 \\
\hline & & Bitkisel Ögeler & 2 & 2 & 2 & 3 & 3 & 3 & 15 \\
\hline & & Kondisyon Aletleri & 3 & 1 & 2 & 2 & 2 & 1 & 11 \\
\hline & & İşaret ve Bilgi Levhaları & 3 & 1 & 2 & 1 & 2 & 1 & 10 \\
\hline & & Sınırlandırıcılar & 3 & 2 & 3 & 2 & 3 & 3 & 16 \\
\hline & & Spor Alanları & 3 & 2 & 3 & 3 & 3 & 3 & 17 \\
\hline & & Toplam puan & 37 & 22 & 30 & 27 & 28 & 32 & 176 \\
\hline \multirow[t]{14}{*}{ Çiftlik Park } & 1543,4 & Alanın Tasarımı & 2 & 1 & 2 & & & 2 & 7 \\
\hline & & Zemin Kaplaması & 2 & 1 & 2 & 2 & 1 & 2 & 10 \\
\hline & & Oyun Alanı Elemanı & 2 & 2 & 3 & 3 & 3 & 2 & 15 \\
\hline & & Oturma Birimleri & - & - & - & - & - & - & - \\
\hline & & Aydınlatma Elemanları & - & - & - & - & - & - & - \\
\hline & & Üst Örtü Ögeleri & - & - & - & - & - & - & - \\
\hline & & Su Ögesi & - & - & - & - & - & - & - \\
\hline & & Çöp kutusu & - & - & - & - & - & - & - \\
\hline & & Bitkisel Ögeler & 1 & 1 & 1 & 1 & 1 & 1 & 6 \\
\hline & & Kondisyon Aletleri & 3 & 1 & 2 & 1 & 1 & 1 & 9 \\
\hline & & İşaret ve Bilgi Levhaları & 2 & 1 & 1 & 2 & 1 & 1 & 8 \\
\hline & & Sınırlandırıcılar & 3 & 1 & 2 & 2 & 2 & 2 & 12 \\
\hline & & Spor Alanları & - & - & - & - & - & - & - \\
\hline & & Toplam puan & 15 & 8 & 13 & 11 & 9 & 11 & 67 \\
\hline \multirow[t]{10}{*}{ Akpınar Parkı } & 1195,61 & Alanın Tasarımı & 3 & 1 & 2 & & & 2 & 8 \\
\hline & & Zemin Kaplaması & 2 & 1 & 2 & 2 & 1 & 2 & 10 \\
\hline & & Oyun Alanı Elemanı & 3 & 2 & 3 & 3 & 3 & 3 & 17 \\
\hline & & Oturma Birimleri & 3 & 1 & 3 & 3 & 3 & 3 & 16 \\
\hline & & Aydınlatma Elemanları & 3 & 1 & 2 & 3 & 3 & 2 & 14 \\
\hline & & Üst Örtü Ögeleri & - & - & - & - & - & - & - \\
\hline & & Su Ögesi & - & - & - & - & - & - & - \\
\hline & & Çöp kutusu & - & - & - & - & - & - & - \\
\hline & & Bitkisel Ögeler & 3 & 1 & 2 & 2 & 3 & 2 & 13 \\
\hline & & Kondisyon Aletleri & 3 & 1 & 3 & 3 & 2 & 2 & 14 \\
\hline
\end{tabular}




\begin{tabular}{llllllll} 
İşaret ve Bilgi Levhaları & 3 & 1 & 2 & 3 & 3 & 3 & 15 \\
\hline Sınırlandırıılar & 3 & 1 & 3 & 3 & 3 & 2 & 15 \\
\hline Spor Alanları & - & - & - & - & - & - & - \\
\hline Toplam puan & $\mathbf{2 6}$ & $\mathbf{1 0}$ & $\mathbf{2 2}$ & $\mathbf{2 2}$ & $\mathbf{2 1}$ & $\mathbf{2 1}$ & $\mathbf{1 2 2}$
\end{tabular}

\subsection{Alan Tasarımı}

Çalışma alanındaki yeşil alanların alan tasarımları fonksiyonellik, estetik, ergonomik ve çevreye uyum kriterleri açısından araştııımıştır. Buna göre incelenen yeşil alanların \%71'inin alan tasarımının fonksiyonelliği yeterli düzeydedir. Alan tasarımının fonksiyonelliği yeterli olan yeşil alanlar: Mevlana, Milli Egemenlik, Cumhuriyet, Aygaz, Mehtap, Gaziler, Rüzgar, Faik Gökalp, Elmas, Prof. Dr. Veysel Eroğlu, Funda, Uğur, Örnek Cami, Merih, Utku, Özge, Uzun, Albayrak, Şirinkent ve Akpınar Parkı'dır. Özyurt, Şirin, Örnek, Sülün ve Çiftlik parklarında alan tasarımı fonksiyonellik açısından kısmen yeterlidir. Fatih Cami, Pınar ve Mersin Parklarında ise alan tasarımı fonksiyonellik açısından yetersizdir.

Parkların \%57'sinin alan tasarımı estetik açıdan yetersiz bulunmuştur. Estetik açıdan yetersiz alan tasarımına sahip yeşil alanlar: Cumhuriyet, Fatih Cami, Mehtap, Pınar, Gaziler, Faik Gökalp, Özyurt, Mersin, Şirin, Örnek, Sülün, Utku, Uzun, Albayrak, Çiftlik ve Akpınar Parklarıdır. Rüzgar ve Şirinkent parklarında alan tasarımı estetik açıdan yeterli seviyededir. Mevlana, Milli Egemenlik, Aygaz, Elmas, Prof. Dr. Veysel Eroğlu, Funda, Uğur, Örnek Cami, Merih ve Özge Parkı'nda ise alan tasarımı estetik açıdan kısmen yeterli puan almıştır.

Incelenen parkların \%21'ini oluşturan Rüzgar, Prof. Dr. Veysel Eroğlu, Funda, Örnek Cami, Özge ve Şirinkent Parklarında alan tasarımının ergonomik olarak yeterli olduğu gözlemlenmiştir. Pınar, Mersin ve Şirin Parklarında ise alan tasarımı ergonomik açıdan yetersiz puan almıştır.

Parkların \%25'inin alan tasarımı çevre ile uyumsuzdur (Fatih Cami, Mehtap, Pınar, Özyurt, Mersin, Şirin ve Örnek parkları). Mevlana, Aygaz, Rüzgar, Prof. Dr. Veysel Eroğlu, Funda, Uğur, Özge ve Şirinkent Parklarında ise alan tasarımı çevre ile uyum içerisindedir. Parkların yaklaşık yarısının (\%46) alan tasarımı çevre ile uyum açısından kısmen yeterli puanı almıştır. Bu yeşil alanlar: Milli Egemenlik, Cumhuriyet, Gaziler, Faik Gökalp, Elmas, Örnek Cami, Sülün, Merih, Utku, Uzun, Albayrak, Çiftlik ve Akpınar Parkı'dır.

\subsection{Zemin Kaplaması}

Araştırma alanındaki yeşil alanların \%32'sinin zemin kaplamasının fonksiyonelliği yeterli düzeydedir. Zemin kaplaması fonksiyonel açıdan yeterlilik gösteren yeşil alanlar şunlardır: Mevlana, Milli Egemenlik, Aygaz, Prof. Dr. Veysel Eroğlu, Özyurt, Funda, Özge, Albayrak ve Şirinkent Parklarıdır. Fonksiyonel açıdan düşük puan alan yeşil alanlar ise Fatih Cami, Pınar, Örnek ve Uzun Parklarıdır.

Kullanılan zemin kaplamasının çoğu parkta estetik açıdan yeterli olmadığı gözlemlenmiştir. Sadece Prof. Dr. Veysel Eroğlu ve Özge Parklarının zemin kaplaması estetik açıdan yeterli puanı almıştır. Zemin kaplaması estetik açıdan yetersiz bulunan yeşil alanlar ise: Milli Egemenlik, Cumhuriyet, Fatih Cami, Mehtap, Pınar, Gaziler, Faik Gökalp, Elmas, Özyurt, Mersin, Şirin, Örnek Cami, Örnek, Sülün, Utku, Uzun, Albayrak, Çiftlik ve Akpınar Parklarıdır.

Ergonomik açıdan zemin kaplaması değerlendirildiğinde Aygaz ve Funda Parkları dışındaki tüm parkların yeterli puan almadığı görülmektedir. Cumhuriyet, Fatih Cami, Mehtap, Pınar, Gaziler, Rüzgar, Faik Gökalp, Mersin, Örnek Cami, Örnek, Sülün ve Uzun Parklarının zemin kaplaması ergonomik açıdan yetersiz bulunmuştur.

Parkların \%21'inin zemin kaplaması dayanıklılık açısından yeterli seviyededir. Zemin kaplaması dayanıklılığı yeterli seviyede olan yeşil alanlar: Aygaz, Elmas, Prof. Dr. Veysel Eroğlu, Funda, Uğur, Şirinkent Parklarıdır. Fatih Cami, Pınar, Mersin, Örnek Cami, Örnek ve Uzun Parklarının zemin kaplamaları dayanıklılık açısından yetersiz puan almıştır.

Parkların \%29'unda zemin kaplamasının bakımı yeterli seviyededir. Milli Egemenlik, Aygaz, Elmas, Prof. Dr. Veysel Eroğlu, Funda, Uğur, Özge ve Şirinkent Parklarının zemin kaplamasının bakımlılığı yeterli seviyede olan yeşil alanlardır. Mevlana, Rüzgar, Faik Gökalp, Özyurt, Şirin, Merih ve Albayrak parklarında zemin kaplamasının bakımının kısmen yeterli olduğu tespit edilmiştir. Cumhuriyet, Fatih 
Cami, Mehtap, Pınar, Gaziler, Mersin, Örnek Cami, Örnek, Sülün, Utku, Uzun, Çiftlik ve Akpınar Parklarında ise zemin kaplamasının bakımının yetersiz olduğu gözlemlenmiştir.

Parkların \%25'inin zemin kaplamasının çevre ile uyum içerisinde olduğu görülmektedir. Mevlana, Milli Egemenlik, Aygaz, Prof. Dr. Veysel Eroğlu, Funda, Özge ve Şirinkent Parklarında yer alan zemin kaplamaları çevre uyum açısından yeterli puanı almıştır. Cumhuriyet, Fatih Cami, Mehtap, Pınar, Gaziler, Özyurt, Örnek Cami, Örnek, Uzun ve Albayrak Parklarında ise zemin kaplamasının çevre uyum konusunda yetersiz olduğu gözlemlenmiştir.

\subsection{Oyun Alanı Elemanları}

İncelenen yeşil alanların \%57'sinde oyun alanı elemanları fonksiyonellik açısından yeterli puanı almıştır. Oyun elemanları fonksiyonellik açısından yeterlilik gösteren yeşil alanlar: Cumhuriyet, Aygaz, Mehtap, Rüzgâr, Prof. Dr. Veysel Eroğlu, Özyurt, Funda, Uğur, Örnek Cami, Merih, Utku, Özge, Uzun, Albayrak, Şirinkent ve Akpınar Parklarıdır. Parkların geri kalanında (\%43) oyun alanı elemanları fonksiyonellik açısından kısmen yeterlidir. Bu yeşil alanlar; Mevlâna, Milli Egemenlik, Fatih Cami, Pınar, Gaziler, Faik Gökalp, Elmas, Mersin, Şirin, Örnek, Sülün ve Çiftlik Parklarıdır.

Yeşil alanların \%36'sında oyun alanı elemanları estetik açıdan yetersiz puan almıştır (Mevlâna, Cumhuriyet, Gaziler, Faik Gökalp, Özyurt, Mersin, Şirin, Örnek, Uzun ve Albayrak Parkları). Rüzgar, Prof. Dr. Veysel Eroğlu, Örnek Cami ve Merih Parklarının oyun alanı elemanları estetik açıdan yeterlidir. Milli Egemenlik, Aygaz, Fatih Cami, Mehtap, Pınar, Elmas, Funda, Uğur, Sülün, Utku, Özge, Şirinkent, Çiftlik ve Akpınar Parklarının ise oyun elemanları estetik açıdan kısmen yeterli puan almıştır.

Yeşil alanların \%32'sini oluşturan Aygaz, Rüzgâr, Örnek Cami, Merih, Utku, Özge, Albayrak, Çiftlik ve Akpınar Parklarında yer alan oyun alanı elemanları ergonomik olarak yeterli düzeydedir. Mevlâna, Milli Egemenlik, Cumhuriyet, Fatih Cami, Mehtap, Pınar, Faik Gökalp, Elmas, Prof. Dr. Veysel Eroğlu, Özyurt, Funda, Uğur, Mersin, Şirin, Örnek, Sülün, Uzun ve Şirinkent Parklarında ise oyun alanı elemanları ergonomik açıdan kısmen yeterlidir. Gaziler Parkı'nda yer alan oyun alanı elemanlarının ergonomik olarak yetersiz olduğu saptanmıştır.

Yeşil alanların \%50'sinde ise oyun alanı elemanlarının dayanıklılık açısından yeterli olduğu gözlemlenmiştir. Oyun elemanları dayanıklılık açısından yeterli olan yeşil alanlar; Milli Egemenlik, Cumhuriyet, Aygaz, Rüzgâr, Elmas, Funda, Uğur, Şirin, Örnek Cami, Merih, Utku, Özge, Çiftlik ve Akpınar Parklarıdır. Mevlâna, Fatih Cami, Mehtap, Pınar, Faik Gökalp, Prof. Dr. Veysel Eroğlu, Özyurt, Mersin, Örnek, Sülün, Uzun, Albayrak ve Şirinkent Parklarında ise oyun alanı elemanları dayanıkııık açısından kısmen yeterlidir. Gaziler Parkı'nda ise oyun alanı elemanları dayanıklııık açısından yetersiz düzeydedir.

Oyun elemanlarının bakımlılı̆ı incelendiğinde yeşil alanların \%54'ünün yeterlilik gösterdiği görülmektedir (Mevlâna, Milli Egemenlik, Cumhuriyet, Aygaz, Rüzgar, Elmas, Prof. Dr. Veysel Eroğlu, Uğur, Şirin, Örnek Cami, Merih, Utku, Özge, Çiftlik ve Akpınar Parkları). Mehtap, Pınar, Gaziler, Faik Gökalp, Özyurt, Funda, Mersin, Örnek, Sülün, Uzun, Albayrak ve Şirinkent Parklarında oyun elemanlarının bakımlılı̆ı kısmen yeterlidir. Fatih Cami Parkı'nda ise oyun elemanlarının bakımının yetersiz olduğu gözlemlenmiştir.

Yeşil alanların \%36'sının (Mevlâna, Aygaz, Rüzgar, Prof. Dr. Veysel Eroğlu, Funda, Uğur, Örnek Cami, Merih, Özge ve Akpınar Parkları) oyun alanı elemanlarının çevre uyumu konusunda yeterli seviyede olduğu tespit edilmiştir. Yeşil alanların \%50'sinde oyun alanı elemanlarının kısmen çevre ile uyumlu olduğu görülmüştür. Oyun alanı elemanlarının çevre ile kısmen uyum içerisinde olduğu yeşil alanlar: Milli Egemenlik, Cumhuriyet, Mehtap, Pınar, Gaziler, Faik Gökalp, Elmas, Şirin, Sülün, Utku, Uzun, Albayrak, Şirinkent ve Çiftlik Parklarıdır. Fatih Cami, Özyurt, Mersin ve Örnek Parklarında ise oyun alanı elemanları çevre ile uyum içerisinde bulunmamıştır.

\subsection{Oturma Birimleri}

Incelenen yeşil alanların \%18'inde oturma birimi bulunmamaktadır. Oturma birimi bulunmayan yeşil alanlar şunlardır: Mevlâna, Fatih Cami, Mehtap, Pınar, Çiftlik Parklarıdır.

Yeşil alanlardaki oturma birimleri Milli Egemenlik, Aygaz, Faik Gökalp, Elmas, Özyurt, Funda, Uğur, Şirin, Örnek Cami, Örnek, Merih, Utku, Özge, Uzun, Albayrak, Şirinkent ve Akpınar Parklarında fonksiyonellik 
açısından yeterli puan almıştır. Cumhuriyet, Rüzgâr, Prof. Dr. Veysel Eroğlu ve Sülün Parklarında ise oturma birimleri fonksiyonellik açısından kısmen yeterlidir. Gaziler ve Mersin Parkında yer alan oturma birimleri ise fonksiyonellik açısından yetersiz bulunmuştur.

Yeşil alanlardaki oturma birimlerinin genel olarak estetik açıdan yetersiz olduğu gözlemlenmiştir (Milli Egemenlik, Gaziler, Rüzgâr, Elmas, Mersin, Örnek Cami, Örnek, Sülün, Albayrak, Şirinkent ve Akpınar Parkları). Cumhuriyet, Aygaz, Faik Gökalp, Prof. Dr. Veysel Eroğlu, Özyurt, Funda, Uğur, Şirin, Merih, Utku, Özge ve Uzun Parklarında ise oturma birimleri estetik açıdan yeterli düzeydedir. Oturma birimleri estetik açısından yeterli puan alan yeşil alan bulunmamaktadır.

Oturma birimleri ergonomik açıdan değerlendirildiğinde, Gaziler, Rüzgâr ve Mersin Parklarında yer alan oturma birimlerinin yetersiz puan aldığı gözlemlenmiştir. Aygaz, Funda, Uğur, Özge ve Akpınar Parklarında yer alan oturma birimleri ergonomik açıdan yeterli puan almıştır. Milli Egemenlik, Cumhuriyet, Faik Gökalp, Elmas, Prof. Dr. Veysel Eroğlu, Özyurt, Şirin, Örnek Cami, Örnek, Sülün, Merih, Utku, Uzun, Albayrak ve Şirinkent Parklarında ise oturma birimleri ergonomik açıdan kısmen yeterli bulunmuştur.

Milli Egemenlik, Rüzgar, Özyurt, Örnek Cami, Örnek, Utku, Albayrak ve Şirinkent Parklarındaki oturma birimleri dayanıkııık açısından kısmen yeterlilik göstermektedir. Cumhuriyet, Gaziler, Mersin ve Sülün Parklarında ise oturma birimlerinin dayanıklılık açısından yetersiz olduğu gözlemlenmiştir.

Aygaz, Faik Gökalp, Prof. Dr. Veysel Eroğlu, Funda, Uğur, Şirin, Merih, Uzun ve Akpınar Parklarında yer alan oturma birimleri bakımlılık açısından yeterli düzeydedir. Milli Egemenlik, Rüzgar, Elmas, Özyurt, Örnek Cami, Örnek, Utku, Özge, Albayrak ve Şirinkent Parklarındaki oturma birimleri bakımlıık açısından kısmen yeterli puan almıştır. Cumhuriyet, Gaziler, Mersin ve Sülün Parklarında ise oturma birimleri bakımlılık açısından yetersiz düzeydedir.

Oturma birimleri çevreye uyum açısından değerlendirildiğinde, Milli Egemenlik, Gaziler, Özyurt, Mersin, Örnek ve Sülün Parkları yetersiz, Aygaz, Prof. Dr. Veysel Eroğlu, Funda, Uğur, Merih, Özge, Şirinkent ve Akpınar Parkları yeterli puan almıştır. Cumhuriyet, Rüzgâr, Faik Gökalp, Elmas, Şirin, Örnek Cami, Utku, Uzun ve Albayrak Parklarının ise oturma birimleri çevreye uyum konusunda kısmen yeterli düzeydedir.

\subsection{Aydınlatma Elemanları}

Yeşil alanların \%25'inde aydınlatma elemanı bulunmamaktadır. Aydınlatma elemanı bulunmayan yeşil alanlar: Mehtap, Pınar, Prof. Dr. Veysel Eroğlu, Örnek, Sülün, Utku, Çiftlik Parklarıdır.

Yeşil alanlarda bulunan aydınlatma elemanları fonksiyonel açıdan değerlendirildiğinde yeşil alanların genelinde aydınlatma elemanları fonksiyonellik açısından yeterli bulunmuştur. Fonksiyonellik açısından yeterli bulunan parklar: Mevlâna, Milli Egemenlik, Aygaz, Faik Gökalp, Elmas, Özyurt, Funda, Uğur, Şirin, Örnek Cami, Merih, Özge, Uzun, Albayrak, Şirinkent ve Akpınar Parklarıdır.

Genel olarak yeşil alanlarda yer alan aydınlatma elemanlarının estetik açıdan yetersiz olduğu gözlemlenmiştir. Aygaz, Rüzgâr, Faik Gökalp, Örnek Cami, Özge ve Uzun parklarında ise aydınlatma elemanları estetik açıdan kısmen yeterlilik göstermiştir. Sadece Mevlâna ve Uğur Parklarında yer alan aydınlatma elemanları estetik açıdan yeterli puan almıştır.

Ergonomik açıdan aydınlatma elemanları değerlendirildiğinde sadece Uğur ve Özge parklarının yeterli puan aldığı görülmektedir. Parkların yaklaşık yarısının (Mevlâna, Milli Egemenlik, Cumhuriyet, Aygaz, Rüzgar, Faik Gökalp, Elmas, Prof. Dr. Veysel Eroğlu, Özyurt, Funda, Mersin, Şirin, Örnek Cami, Merih, Uzun, Albayrak, Şirinkent ve Akpınar Parkları) aydınlatma elemanları ergonomik açıdan kısmen yeterli puan almıştır. Fatih Cami ve Gaziler parkında yer alan aydınlatma elemanları ise ergonomik açıdan yetersizdir.

Mevlâna, Milli Egemenlik, Uğur ve Akpınar Parklarında bulunan aydınlatma elemanlarının bakımı yeterli düzeydedir. Aydınlatma elemanlarının bakımı yetersiz olan yeşil alan bulunmamaktadır. 
Çevre uyum konusunda ise sadece Uğur Parkı'nda yer alan aydınlatma elemanları yeterli puanı almıştır. Cumhuriyet, Fatih Cami, Gaziler, Faik Gökalp, Elmas, Özyurt, Funda, Şirin, Örnek Cami, Merih ve Albayrak Parklarında yer alan aydınlatma elemanları çevre uyum açısından yetersiz puan almıştır.

\section{6. Üst Örtü Ögeleri}

Çalışma alanında incelenen yeşil alanların sadece \%21'inde (6 parkta) üst örtü ögeleri bulunmaktadır. Tüm yeşil alanlarda üst örtü ögelerinin fonksiyonelliği yeterli seviyedir. Estetik açıdan üst örtü ögeleri, Mevlâna, Milli Egemenlik, Rüzgâr ve Şirinkent Parklarında kısmen yeterli puanı almıştır. Cumhuriyet ve Uğur Parklarında ise üst örtü ögeleri estetik olarak yetersiz bulunmuştur.

Milli Egemenlik ve Şirinkent Parklarında yer alan üst örtü ögeleri ergonomik açıdan yeterlidir. Mevlâna, Rüzgâr ve Uğur Parklarındaki üst örtü ögeleri ergonomik açıdan kısmen yeterli puan alırken, Cumhuriyet Parkı'nda ise üst örtü öğelerinin ergonomik açıdan yetersiz olduğu saptanmıştır.

Dayanıklılık açısından değerlendirildiğinde üst örtü ögeleri, Mevlâna, Milli Egemenlik ve Şirinkent Parklarında yeterli düzeydedir. Cumhuriyet, Rüzgâr ve Uğur Parklarında ise üst örtü öğelerinin dayanıklılık açısından kısmen yeterli olduğu gözlemlenmiştir.

Mevlâna, Milli Egemenlik ve Şirinkent Parklarında yer alan üst örtü ögelerinin bakımı yeterli düzeydeyken, Cumhuriyet Parkında ise yetersiz seviyededir. Rüzgâr ve Uğur Parklarında ise üst örtü ögelerinin bakımı kısmen yeterlidir.

Şirinkent Parkında yer alan üst örtü ögeleri çevre ile uyum içerisindedir. Mevlâna, Milli Egemenlik, Rüzgar ve Uğur Parklarında çevre ile uyumun kısmen yeterli düzeyde olduğu görülmektedir. Cumhuriyet Parkında ise üst örtü ögelerinin çevre ile uyumsuz olduğu tespit edilmiştir.

\subsection{Su Ögeleri}

Su ögeleri çalışma alanındaki yeşil alanların sadece $\% 18^{\prime}$ inde (5 parkta) bulunmaktadır. Şirinkent Parkı dışındaki yeşil alanlarda yer alan su ögeleri fonksiyonellik açısından yetersiz bulunmuştur. Aynı zamanda bu parklarda yer alan su ögeleri estetik açıdanda yeterli bulunmamıştır. Fonksiyonellik ve estetik açısından su öğelerinin yetersiz bulunduğu yeşil alanlar: Milli Egemenlik, Aygaz, Prof. Dr. Veysel Eroğlu ve Uğur Parklarıdır.

Şirinkent Parkı'nda bulunan su ögeleri ergonomik açıdan kısmen yeterli bulunurken, Milli Egemenlik, Aygaz, Prof. Dr. Veysel Eroğlu ve Uğur Parklarında ergonomik açıdan yetersiz olduğu gözlemlenmiştir.

Milli Egemenlik, Uğur ve Şirinkent Parklarında su ögelerinin dayanıklılığı kısmen yeterli düzeydedir. Aygaz ve Prof. Dr. Veysel Eroğlu Parklarında yer alan su öğelerinin ise dayanıklılık açısından yetersiz olduğu tespit edilmiştir.

Tüm yeşil alanlardaki su ögelerinin bakımsız olduğu görülmüştür. Şirinkent Parkında yer alan su ögesi çevre ile uyum içerisindedir. Uğur Parkında bulunan su ögesinin çevre ile kısmen uyum içerisinde olduğu saptanmıştır. Milli Egemenlik, Aygaz ve Prof. Dr. Veysel Eroğlu Parklarında ise su öğelerinin çevre ile uyumsuz olduğu gözlemlenmiştir.

\section{8. Çöp Kutuları}

Çöp kutusu çalışma alanındaki yeşil alanların sadece \%32'sinde (9 parkta) bulunmaktadır. Bu yeşil alanların \%67'sinde çöp kutuları fonksiyonel açıdan yeterli puan almıştır. Bu yeşil alanlar: Faik Gökalp, Funda, Uğur, Merih, Utku ve Şirinkent Parklarıdır. Mevlâna, Cumhuriyet ve Aygaz Parklarında ise çöp kutuları fonksiyonel açıdan kısmen yeterli bulunmuştur. Tüm yeşil alanlarda yer alan çöp kutularının estetik açıdan yetersiz olduğu gözlemlenmiştir.

Çöp kutusu bulunan yeşil alanların \%78'inde çöp kutuları ergonomik açıdan kısmen yeterli puan almıştır. Bu yeşil alanlar: Cumhuriyet, Faik Gökalp, Funda, Uğur, Merih, Utku ve Şirinkent Parklarıdır. Mevlâna ve Aygaz Parklarında ise çöp kutuları ergonomik açıdan yeterli seviyede bulunmamıştır.

Çöp kutusu yer alan yeşil alanların \%56'sında çöp kutuları dayanıklılık açısından yeterli seviyede bulunmuştur. Dayanıklıık açısından kısmen yeterli puanı alan yeşil alanlar: Mevlâna, Uğur, Merih, Utku 
ve Şirinkent Parklarıdır. Cumhuriyet, Aygaz, Faik Gökalp ve Funda Parklarında ise çöp kutularının dayanıklıık açısından yetersiz olduğu tespit edilmiştir.

Uğur, Merih ve Şirinkent Parklarındaki çöp kutularının bakımı kısmen yeterlidir. Mevlâna, Cumhuriyet, Aygaz, Faik Gökalp, Funda ve Utku Parklarında ise çöp kutularının bakımının yeterli seviyede olmadığı gözlemlenmiştir.

Çevre ile uyumu değerlendirilen çöp kutularının, Şirinkent Parkı haricindeki bütün yeşil alanlarda uyumsuz olduğu gözlemlenmiştir.

\subsection{Bitkisel Ögeler}

Çalışma alanında yer alan Mehtap ve Şirin Parklarında hiçbir bitkisel öğeye rastlanmamıştır. Bitkisel ögelerin yalnızca Akpınar Parkı'nda fonksiyonel açıdan yeterli olduğu gözlemlenmiştir. Yeşil alanların \%58'inde bitkisel ögeler fonksiyonellik açısından kısmen yeterlidir. Bu yeşil alanlar: Mevlâna, Cumhuriyet, Aygaz, Gaziler, Rüzgar, Faik Gökalp, Elmas, Prof. Dr. Veysel Eroğlu, Özyurt, Funda, Uğur, Utku, Özge, Albayrak ve Şirinkent Parklarıdır. Milli Egemenlik, Fatih Cami, Pınar, Mersin, Örnek Cami, Örnek, Sülün, Merih, Uzun ve Çiftlik Parklarında ise bitkisel ögelerin fonksiyonellik açısından yetersiz olduğu tespit edilmiştir.

Estetik açıdan değerlendirilen bitkisel ögeler parkların hiçbirinde yeterlilik gösterememiştir. Bitkisel ögeleri estetik açıdan kısmen yeterli olduğu yeşil alanlar: Faik Gökalp, Prof. Dr. Veysel Eroğlu, Funda, Uğur ve Şirinkent Parklarıdır. Yeşil alanların \%81'inde bitkisel ögeler hiçbir estetik kaygı taşımamaktadır. Bu yeşil alanlar: Mevlâna, Milli Egemenlik, Cumhuriyet, Aygaz, Fatih Cami, Pınar, Gaziler, Rüzgâr, Elmas, Özyurt, Mersin, Örnek Cami, Örnek, Sülün, Merih, Utku, Özge, Uzun, Albayrak, Çiftlik ve Akpınar Parklarıdır.

Bitkisel öğeler peyzaj ergonomisi açısından değerlendirildiğinde Faik Gökalp ve Uğur parklarında yeterli puan alırken, Mevlâna, Milli Egemenlik, Aygaz, Rüzgâr, Elmas, Prof. Dr. Veysel Eroğlu, Funda, Şirinkent ve Akpınar Parklarında kısmen yeterli puan almıştır. Parkların \%58'inde bitkisel ögelerin peyzaj ergonomisi açısından yetersiz olduğu saptanmıştır. Cumhuriyet, Fatih Cami, Pınar, Gaziler, Özyurt, Mersin, Örnek Cami, Örnek, Sülün, Merih, Utku, Özge, Uzun, Albayrak ve Çiftlik Parklarında yer alan bitkisel ögeler ise peyzaj ergonomisi açısından yetersiz bulunmuştur.

Bitkisel ögeler ortam koşullarına dayanıklılık açısından değerlendirildiğinde Faik Gökalp, Prof. Dr. Veysel Eroğlu ve Şirinkent Parklarında yeterli puanı almıştır. Yeşil alanların \%42'sinde bitkisel ögeler ortam koşullarına dayanıklıık açısından kısmen yeterli seviyededir. Mevlâna, Milli Egemenlik, Cumhuriyet, Aygaz, Pınar, Elmas, Funda, Uğur, Sülün, Merih ve Akpınar Parklarında bitkisel ögelerin ortam koşullarına dayanıklılık açısından kısmen yeterli olduğu görülmüştür. Fatih Cami, Gaziler, Rüzgâr, Özyurt, Mersin, Örnek Cami, Örnek, Utku, Özge, Uzun, Albayrak ve Çiftlik Parklarında ise bitkisel ögelerin ortam koşullarına dayanıklılık açısından yetersiz olduğu gözlemlenmiştir.

Faik Gökalp, Funda, Uğur, Şirinkent ve Akpınar Parklarında bulunan bitkisel ögelerinin bakımının yeterli düzeyde olduğu tespit edilmiştir. Mevlâna, Milli Egemenlik, Aygaz, Pınar ve Prof. Dr. Veysel Eroğlu Parklarında ise bitkisel ögelerin bakımının kısmen yeterli olduğu görülmüştür. Parkların \%62'sinde bitkisel ögelerin bakımının yetersiz olduğu gözlemlenmiştir. Bu yeşil alanlar: Cumhuriyet, Fatih Cami, Gaziler, Rüzgâr, Elmas, Özyurt, Mersin, Örnek Cami, Örnek, Sülün, Merih, Utku, Özge, Uzun, Albayrak ve Çiftlik Parklarıdır.

Faik Gökalp, Prof. Dr. Veysel Eroğlu, Uğur ve Şirinkent Parklarında yer alan bitkisel ögelerin çevre ile uyumlu olduğu görülmüştür. Mevlâna, Aygaz, Elmas, Funda ve Akpınar Parklarında ise bitkisel öğelerin çevre ile kısmen uyumlu olduğu görülmüştür. Yeşil alanların $\% 65$ 'inde bitkisel ögeler çevre ile uyumsuzdur. Bitkisel ögelerin çevre ile uyumunun yetersiz bulunduğu yeşil alanlar: Milli Egemenlik, Cumhuriyet, Fatih Cami, Pınar, Gaziler, Rüzgâr, Özyurt, Mersin, Örnek Cami, Örnek, Sülün, Merih, Utku, Özge, Uzun, Albayrak ve Çiftlik Parklarıdır. 


\subsection{Kondisyon Aletleri}

Çalışma alanında yer alan yeşil alanların \%79'unda kondisyon aleti bulunmaktadır. Kondisyon aleti bulunmayan yeşil alanlar şunlardır: Milli Egemenlik, Cumhuriyet, Aygaz, Fatih Cami, Mehtap ve Özyurt Parkları.

Yeşil alanların \%82'sinde kondisyon aletleri fonksiyonellik açısından yeterli düzeydedir. Bu yeşil alanlar: Gaziler, Rüzgâr, Faik Gökalp, Elmas, Prof. Dr. Veysel Eroğlu, Funda, Uğur, Mersin, Şirin, Örnek Cami, Merih, Utku, Özge, Uzun, Albayrak, Şirinkent, Çiftlik ve Akpınar Parklarıdır. Mevlâna, Örnek ve Sülün Parklarında yer alan kondisyon aletlerinin fonksiyonellik açısından kısmen yeterli düzeyde olduğu görülmüştür. Pınar Parkı'nda ise kondisyon aletlerinin fonksiyonelliğinin yetersiz olduğu tespit edilmiştir.

Estetik açıdan değerlendirilen kondisyon aletleri Rüzgâr ve Merih Parkları dışında diğer yeşil alanlarda yetersiz bulunmuştur. Mevlâna, Pınar, Gaziler, Faik Gökalp, Elmas, Prof. Dr. Veysel Eroğlu, Funda, Uğur, Mersin, Şirin, Örnek Cami, Örnek, Sülün, Utku, Özge, Uzun, Albayrak, Şirinkent, Çiftlik ve Akpınar Parklarında ise kondisyon aletlerinin estetik açıdan yetersiz olduğu tespit edilmiştir.

Ergonomik açıdan sadece Akpınar Parkı'nda yer alan kondisyon aletlerinin yeterli puanı aldığı görülmüştür. Yeşil alanların \%91'inde bulunan kondisyon aletleri kısmen yeterli düzeydedir. Bu yeşil alanlar: Mevlâna, Gaziler, Rüzgâr, Faik Gökalp, Elmas, Prof. Dr. Veysel Eroğlu, Funda, Uğur, Mersin, Şirin, Örnek Cami, Örnek, Sülün, Merih, Utku, Özge, Uzun, Albayrak, Şirinkent ve Çiftlik Parklarıdır. Pınar Parkı'nda ise kondisyon aletlerinin ergonomik açıdan yetersiz olduğu görülmüştür.

Rüzgâr, Merih ve Akpınar Parklarında yer alan kondisyon aletleri dayanıklılık açısından yeterli puan almıştır. Yeşil alanların \%77'sinde kondisyon aletlerinin dayanıkııık açısından kısmen yeterli puan aldığı görülmüştür. Bu yeşil alanlar: Mevlâna, Pınar, Gaziler, Faik Gökalp, Elmas, Prof. Dr. Veysel Eroğlu, Funda, Uğur, Mersin, Şirin, Örnek Cami, Örnek, Sülün, Utku, Uzun, Albayrak ve Şirinkent Parklarıdır. Özge ve Çiftlik parklarında bulunan kondisyon aletlerinin dayanıklılığı yetersizdir.

Rüzgâr ve Merih parklarında yer alan kondisyon aletlerinin bakımlılığı yeterlidir. Yeşil alanların \%73'ünde kondisyon aletlerinin bakımının kısmen yeterli olduğu tespit edilmiştir. Bu yeşil alanlar: Mevlâna, Pınar, Gaziler, Faik Gökalp, Elmas, Prof. Dr. Veysel Eroğlu, Funda, Uğur, Mersin, Örnek Cami, Örnek, Utku, Uzun, Albayrak, Şirinkent ve Akpınar Parklarıdır. Şirin, Sülün, Özge ve Çiftlik Parklarında ise kondisyon aletlerinin bakımının yetersiz olduğu tespit edilmiştir.

Çevre ile uyumu değerlendirilen kondisyon aletlerinin sadece Rüzgâr Parkında yeterli puan aldığı görülmüştür. Gaziler, Merih, Uzun ve Akpınar Parklarında kondisyon aletlerinin çevre ile uyumunun kısmen yeterli olduğu dikkat çekmektedir. Parkların \%77'sinde kondisyon aletleri çevre ile uyumsuzdur. Çevre ile uyumsuz olan yeşil alanlar: Mevlâna, Pınar, Faik Gökalp, Elmas, Prof. Dr. Veysel Eroğlu, Funda, Uğur, Mersin, Şirin, Örnek Cami, Örnek, Sülün, Utku, Özge, Albayrak, Şirinkent ve Çiftlik Parklarıdır.

\subsection{1. İşaret ve Bilgi Levhaları}

Çalışma alanında yer alan yeşil alanların \%61'inde işaret ve bilgi levhaları bulunmaktadır. İşaret ve bilgi levhası bulunmayan yeşil alanlar: Cumhuriyet, Aygaz, Fatih Cami, Gaziler, Faik Gökalp, Özyurt, Funda, Mersin, Örnek, Sülün ve Uzun Parklarıdır.

Çalışma alanındaki yeşil alanların \%29'unda yer alan işaret ve bilgi levhaları fonksiyonel olarak yeterli düzeydedir. Bu yeşil alanlar: Merih, Utku, Özge, Şirinkent ve Akpınar Parklarıdır. Milli Egemenlik, Elmas, Prof. Dr. Veysel Eroğlu, Uğur, Şirin, Örnek Cami, Albayrak ve Çiftlik Parklarında bulunan işaret ve bilgi levhalarının işlevselliği kısmen yeterli bulunmuştur. Mevlâna, Mehtap, Pınar ve Rüzgâr Parklarında ise işaret ve bilgi levhalarının fonksiyonelliklerini kaybettiği görülmüştür.

Estetik açıdan değerlendirilen işaret ve bilgi levhaları Prof. Dr. Veysel Eroğlu ve Örnek Cami Parkları dışındaki tüm yeşil alanlarda yetersiz olduğu görülmüştür. Mevlâna, Milli Egemenlik, Mehtap, Pınar, Rüzgâr, Elmas, Uğur, Şirin, Merih, Utku, Özge, Albayrak, Şirinkent, Çiftlik ve Akpınar Parklarında işaret ve bilgi levhaları estetik açıdan yetersiz bulunmuştur. 
Yeşil alanların \%59'unda işaret ve bilgi levhalarının ergonomik açıdan kısmen yeterli olduğu görülmüştür. Kısmen yeterli puan alan yeşil alanlar: Mevlâna, Mehtap, Elmas, Prof. Dr. Veysel Eroğlu, Uğur, Örnek Cami, Merih, Albayrak, Şirinkent ve Akpınar Parklarıdır. Milli Egemenlik, Pınar, Rüzgâr, Şirin, Utku, Özge ve Çiftlik Parklarında ise işaret ve bilgi levhalarının ergonomik açıdan yetersiz olduğu tespit edilmiştir.

Sadece Elmas, Prof. Dr. Veysel Eroğlu ve Akpınar Parklarında dayanıklılık açısından yeterli bulunan işaret ve bilgi levhaları, Mevlâna, Mehtap, Pınar, Uğur, Şirin, Örnek Cami, Merih ve Çiftlik Parklarında ise kısmen yeterli düzeydedir. Milli Egemenlik, Rüzgâr, Utku, Özge, Albayrak ve Şirinkent Parklarında yer alan işaret ve bilgi levhalarının ise dayanıklılık açısından yetersiz olduğu gözlemlenmiştir.

Mevlâna ve Akpınar Parklarında bulunan işaret ve bilgi levhalarının bakımı yeterli düzeydedir. Mehtap, Pınar, Rüzgâr, Elmas, Prof. Dr. Veysel Eroğlu, Uğur, Şirin, Örnek Cami, Merih ve Şirinkent Parklarındaki işaret ve bilgi levhalarının bakımı ise kısmen yeterlidir. Milli Egemenlik, Utku, Özge, Albayrak ve Çiftlik Parklarında işaret ve bilgi levhalarının bakımının yetersiz olduğu tespit edilmiştir.

Prof. Dr. Veysel Eroğlu ve Akpınar Parklarında işaret ve bilgi levhalarının çevre ile uyumlu olduğu görülmektedir. Mevlâna, Mehtap, Rüzgar ve Elmas Parklarında ise işaret ve bilgi levhaları çevre ile kısmen uyumludur. Milli Egemenlik, Pınar, Uğur, Şirin, Örnek Cami, Merih, Utku, Özge, Albayrak, Şirinkent ve Çiftlik Parklarında ise işaret ve bilgi levhaları çevre ile uyumsuz bulunmuştur.

\subsection{Sınırlandırıcılar}

Pınar, Özyurt, Şirin ve Uzun parklarında sınırlandırııı eleman bulunmamaktadır. Sınırlandırıcı eleman bulunan yeşil alanların \%63'ünde sınırlandırıcılar fonksiyonellik açısından yeterli puan almıştır. Sınırlandırıcı elemanları fonksiyonellik açısından yeterli bulunan yeşil alanlar: Mevlâna, Milli Egemenlik, Aygaz, Rüzgar, Faik Gökalp, Elmas, Funda, Uğur, Örnek Cami, Merih, Utku, Albayrak, Şirinkent, Çiftlik ve Akpınar Parklarıdır. Cumhuriyet, Fatih Cami, Mehtap, Gaziler, Prof. Dr. Veysel Eroğlu, Örnek, Sülün ve Özge Parklarında yer alan sınırlandırıcı elemanlar fonksiyonellik açısından kısmen yeterli puan almıştır. Mersin Parkı'nda bulunan sınırlandırıcı elemanlar ise fonksiyonellik açısından yetersiz bulunmuştur.

Yeşil alanların \%46'sında sınırlandırııılar estetik açıdan kısmen yeterli puan almıştır. Bu yeşil alanlar: Mevlâna, Aygaz, Rüzgar, Faik Gökalp, Prof. Dr. Veysel Eroğlu, Uğur, Örnek Cami, Merih, Utku, Özge ve Şirinkent Parklarıdır. Milli Egemenlik, Cumhuriyet, Fatih Cami, Mehtap, Gaziler, Elmas, Funda, Mersin, Örnek, Sülün, Albayrak, Çiftlik ve Akpınar Parklarında yer alan sınırlandırııılar estetik açıdan yetersiz puan almıştır.

Yeşil alanların \%33'ünde sınırlandırıcıların ergonomik açıdan yeterli olduğu görülmüştür. Ergonomik açıdan yeterli puan alan yeşil alanlar: Aygaz, Uğur, Örnek Cami, Merih, Utku, Özge, Şirinkent ve Akpınar Parklarıdır. Mevlâna, Milli Egemenlik, Cumhuriyet, Mehtap, Rüzgar, Faik Gökalp, Elmas, Prof. Dr. Veysel Eroğlu, Funda, Mersin, Örnek, Sülün, Albayrak ve Çiftlik Parklarında yer alan sınırlandırıcılar ergonomik açıdan kısmen yeterli bulunmuştur. Fatih Cami ve Gaziler Parklarında ise sınırlandırıııların ergonomik açıdan yetersiz olduğu tespit edilmiştir.

Parkların \%38'inde sınırlandırııılar dayanıklılık açısından yeterli puan almıştır. Bu yeşil alanlar: Aygaz, Rüzgâr, Faik Gökalp, Prof. Dr. Veysel Eroğlu, Uğur, Örnek Cami, Merih, Özge ve Akpınar Parklarıdır. Mevlâna, Cumhuriyet, Mehtap, Elmas, Funda, Mersin, Örnek, Sülün, Utku, Albayrak, Şirinkent ve Çiftlik Parklarında sınırlandırıcılar dayanıkııık açısından kısmen yeterli bulunmuştur. Milli Egemenlik, Fatih Cami ve Gaziler Parklarında ise sınırlandırıııların dayanıklılık açısından yetersiz olduğu gözlemlenmiştir.

Yeşil alanların \%38'inde sınırlandırıcıların bakımı yeterli seviyededir. Bakım açısından yeterli puan alan yeşil alanlar: Mevlâna, Cumhuriyet, Rüzgâr, Faik Gökalp, Uğur, Örnek Cami, Özge, Şirinkent ve Akpınar Parklarıdır. Milli Egemenlik, Aygaz, Elmas, Prof. Dr. Veysel Eroğlu, Funda, Örnek, Sülün, Merih, Utku, Albayrak ve Çiftlik Parklarında bulunan sınırlandırıcıların bakımı kısmen yeterli bulunup, Fatih Cami, Mehtap, Gaziler ve Mersin Parklarında ise yetersiz olduğu görülmüştür.

Yeşil alanların \%25'inde sınırlandırıcıların çevre ile uyum içerisinde olduğu görülmüştür. Sınırlandırıcıların çevre ile uyum içerisinde olduğu yeşil alanlar: Rüzgâr, Prof. Dr. Veysel Eroğlu, Uğur, 
Örnek Cami, Özge ve Şirinkent Parklarıdır. Mevlâna, Cumhuriyet, Aygaz, Faik Gökalp, Elmas, Örnek, Sülün, Merih, Utku, Albayrak, Çiftlik ve Akpınar Parklarında bulunan sınırlandırıcı elemanların çevre ile kısmen uyumlu olduğu tespit edilmiştir. Milli Egemenlik, Fatih Cami, Mehtap, Gaziler, Funda ve Mersin Parklarında ise sınırlandırıcı elemanlar çevre ile uyumsuz bulunmuştur.

\subsection{Spor Alanları}

Spor alanları incelenen 28 park içerisinden sadece; Pınar, Rüzgâr, Uğur, Özge, Uzun, Albayrak ve Şirinkent Parklarında yer almaktadır. Spor alanı bulunan yeşil alanların \%86'sının spor alanları fonksiyonellik açısından yeterli puan almıştır. Bu yeşil alanlar: Rüzgâr, Uğur, Özge, Uzun, Albayrak ve Şirinkent Parklarıdır. Pınar Parkı'nın spor alanı fonksiyonellik açısından kısmen yeterli bulunmuştur.

Yeşil alanların \%43'ünün spor alanı estetik açıdan kısmen yeterli düzeydedir. Bu yeşil alanlar: Rüzgâr, Özge ve Şirinkent Parklarıdır. Pınar, Uğur, Uzun ve Albayrak Parklarında ise spor alanları estetik açıdan yetersiz bulunmuştur.

Parkların \%43'ünde yer alan spor alanları ergonomik açıdan yeterli seviyededir. Spor alanları ergonomik açıdan yeterli bulunan yeşil alanlar: Özge, Albayrak ve Şirinkent Parklarıdır. Pınar, Rüzgâr ve Uğur Parklarında bulunan spor alanları ergonomik açıdan kısmen yeterli puan almıştır. Uzun Park'ta ise spor alanları ergonomik açıdan yetersiz bulunmuştur.

Yeşil alanların \%57'sinde spor alanları dayanıklılık açısından yeterli puan almıştır. Bu yeşil alanlar: Rüzgâr, Özge, Albayrak ve Şirinkent Parklarıdır. Pınar, Uğur ve Uzun Parklarında ise spor alanlarının dayanıklılık açısından kısmen yeterli olduğu görülmüştür.

Yeşil alanların \%43'ünde spor alanlarının bakımı yeterli düzeydedir. Bu yeşil alanlar: Özge, Albayrak ve Şirinkent Parklarıdır. Pınar, Rüzgâr, Uğur ve Uzun Parklarında ise spor alanlarının bakımının kısmen yeterli olduğu gözlemlenmiştir.

Çevre ile uyum açısından değerlendirilen parklardan sadece Şirinkent Parkı'nın spor alanı yeterli puan almıştır. Rüzgâr, Uğur, Özge ve Albayrak Parklarındaki spor alanlarının çevre ile uyumunun kısmen yeterli olduğu gözlemlenmiştir. Uzun ve Pınar Parklarında ise spor alanlarının çevre ile uyumunun bulunmadığı tespit edilmiştir.

\section{Sonuç ve Öneriler}

Bu çalışmada Uşak kenti Cumhuriyet Mahallesi yeşil alanlarında (park ve çocuk bahçesi) yer alan donatı elemanlarının belirlenen kriterler doğrultusunda değerlendirilmesi amaçlanmıştır. Çalışma alanındaki yeşil alanların fonksiyonellik, estetik, ergonomi, dayanıklılık, bakım ve çevreye uyum açısından irdelenmesi sonucu elde edilen bulgular değerlendirilmiştir.

Yapılan gözlemlere göre yeşil alanların \%71'inin alan tasarımının fonksiyonelliği yeterlidir. Yeşil alanların \%57'sinin alan tasarımı estetik açıdan yetersizdir.Yeşil alanların \%21'inde alan tasarımı ergonomik açıdan yeterli olup, yeşil alanların $\% 75^{\prime}$ inde ise alan tasarımı çevre ile uyumludur.

Sert zemin, kum ve çimden oluşan zemin kaplamalarının genel olarak fonksiyonel açıdan yeterli olduğu gözlemlenmiştir. Fakat zemin kaplamaları kısmen çevre ile uyumludur. Ayrıca zemin kaplamalarının yeşil alanların çoğunda estetik olarak yetersiz olduğu görülmektedir. Zemin kaplamalarının estetik açıdan yetersiz olmasındaki en büyük neden zemin kaplamalarının bakımsızlığıdır.

Incelenen yeşil alanların çoğunda yer alan oyun elemanları fonksiyonel açıdan yeterlidir. Ancak parklarda standart tekdüze oyun alanı elemanı tasarımı gözlemlenmiştir.

Yeşil alanlarda bulunan aydınlatma elemanları genel olarak fonksiyonel açıdan yeterliyken, estetik ve çevre ile uyum açısından yetersiz bulunmuştur. Ergonomi, dayanıklılık ve bakım kriterlerinde ise kısmen yeterlilik göstermiştir.

Yeşil alanların büyük çoğunluğunda üst örtü bulunmadığı görülmektedir. Üst örtüler genel olarak fonksiyonel, bakım ve dayanıklılık kriterleri açısından yeterli, estetik, ergonomik ve çevre ile uyum açısından kısmen yeterlidir. 
Su ögeleri, incelenen yeşil alanların bazılarında bulunmaktadır. Su ögelerinin, tasarımları ve işlevlerinin yetersiz olduğu tespit edilmiştir. Tasarımdaki eksiklikler, su ögelerinin çevre ile uyumsuzluğuna neden olmuştur.

Çöp kutuları yeşil alanların çoğunda bulunmamaktadır. Kullanılan çöp kutuları genel olarak estetik ve bakım açısından yetersiz ve çevre ile uyumsuzdur.

Yeşil alanların en önemli ögelerinden biri olan bitkisel ögeler, incelenen yeşil alanların çoğunda yetersiz bulunmuştur. Bitkisel tasarımda ve bitkilerin bakımı konusunda önemli eksikliklerin olduğu dikkat çekmektedir.

Kondisyon aletleri ile işaret ve bilgi levhaları yeşil alanların çoğunda ergonomik, dayanıklılık ve bakım açısından kısmen yeterlidir. Ancak estetik ve çevreye uyum açısından yetersizdir.

Tel ve taş duvardan oluşan sınırlandırııılar, fonksiyonel olarak yeterlidir. Ancak diğer kriterler açısından kısmen yeterlilik göstermiştir.

Spor alanları yeşil alanların az kısmında bulunmaktadır. Spor alanları genel olarak incelenen kriterlerde yeterlilik göstermiştir.

Bu bağlamda incelenen kriterler doğrultusunda Uşak kenti Cumhuriyet Mahallesi'ndeki yeşil alanlarının nicelik açısından kentte en çok yeşil alan sayısına sahip mahalle olmasına rağmen, nitelik açısından yetersiz olduğu sonucuna ulaşılmıştır. Kullanılan donatı elemanlarının standart, tekdüze ve hemen hemen birbirinin aynısı olduğu gözlemlenmiştir. Farklı tasarım yaklaşımları, farklı malzeme vb. kullanımı oldukça azdır. Sağlık ve diğerleri. (2014), çalışmasında donatı elemanlarının en önemli sorunlarının tasarım hatalarından kaynaklı kullanım zorluğu, kalitesiz malzeme, estetik kaygının olmaması, yanlış konumlandırma olduğunu belirtmiştir. Bitkisel, zemin ve donatı elemanlarında tasarım süreci, tasarımı doğru uygulama, tasarımın ekolojik koşullara uyumu ve dayanıklılı̆ı, profesyonel anlamda yapılması gereken önemli bir süreçtir ve doğru kararlarla insan kullanımına en uygun yaklaşımlar ancak bu şekilde ortaya çıkmaktadır. Bir mekân kullanıldıkça yaşar ve kullanılan her türlü kentsel ve çevresel donatı elemanlarının hem fonksiyonel hem de renk, doku, biçim gibi tasarım öğeleri açısından ergonomik olması oldukça önemlidir (Akpınar Külekçi, 2018b). Çalışma alanında incelenen donatı elemanlarının bu belirtilen sorunları olduğu gözlemlenmiştir. Yeşil alanlarda birçok açıdan önemli eksiklikler tespit edilmiş olup kullanıııya hizmet sunma ve kentin ihtiyacını karşılaması konusunda yeşil alanların önemli sorunları bulunduğu tespit edilmiştir. Çalışma alanında yeşil alanların sorunlarının en büyük nedenleri genel olarak şu şekilde sıralanabilir;

- Alan tasarımlarının projelendirme, uygulama ve yönetimi aşamasındaki sorunlar

- Alan tasarımlarında ekolojik, sosyo-kültürel, psikolojik, teknolojik unsurların göz ardı edilmesi,

- Alan tasarımlarında kullanıı intiyaçlarının yeterince belirlenmemesi,

- Alan tasarımlarının tasarım ilkeleri doğrultusunda yapılmaması,

- Alan tasarımında kullanılan donatı elemanlarının bütüncül olarak ele alınmaması,

- Alan tasarımlarında sürdürülebilirlik ilkesi gözetilmemesi,

- Alan tasarımlarında nitelikten çok niceliğe önem verilmesi,

- Uşak Belediyesi Park ve Bahçeler Müdürlüğü'ndeki personel eksikliği,

- Belediyenin yeşil alanlar için ayırmış olduğu bütçenin kısıtlı olması.

Yukarıda belirtilen eksikliklerden dolayı incelenen yeşil alanların ve kullanılan donatı elemanlarının kalitesinin oldukça düşük olduğu ve kent kimliğiyle olan ilişkisinin olumsuz olduğu söylenebilir. Bu sonuçlar ülke genelindeki sonuçlarla benzer niteliktedir. Ülkemizdeki birçok çalışmada yeşil alanların ve kullanılan donatı elemanlarının kalitesinin düşük olduğu ve kent kimliğiyle ilişkisinin olumsuz olduğu görülmektedir. Bayramoğlu ve Özdemir (2011) araştırmasında, Trabzon kenti Uzun Sokak'ta yer alan donatı elemanlarının kent kimliğiyle uyumlu olmadığını tespit etmiştir. Sağlık ve diğerleri (2014) çalışmasında, Çanakkale kent merkezinde donatı elemanlarının çeşitli sorunları olduğunu saptamıştır. Özgeriş (2018) çalışmasında, Erzurum kent merkezinde kullanılan donatı elemanlarının kent kimliğiyle uyumsuz olduğunu gözlemlemiştir. Kuter ve Kaya (2019) araştırmasında, Çankırı kent merkezinde 
incelediği alanlarda donatı elemanlarının estetik, bakım vb. sorunları bulunduğu ve kent ile bütünlük sağlamadığını tespit etmiştir. Bu araştırmalarda ulaşılan sonuçlar bu çalışmada ulaşılan sonuçlar ile benzerlik göstermektedir.

Uşak kenti Cumhuriyet Mahallesi'ndeki yeşil alanların ve donatı elemanlarının kalitesinin yükseltilmesi için mutlaka yeşil alanların ve donatı elemanlarının fonksiyonellik, estetik, ergonomi, dayanıklılık, bakım ve çevre uyum kriterleri dikkate alınarak, kent kimliğiyle uyumlu, bütüncül ve kullanıcının taleplerine cevap verecek şekilde eksikliklerinin giderilmesi için önem arz etmektedir.

\section{Teşekkür ve Bilgi Notu}

Makalede ulusal ve uluslararası araştırma ve yayın etiğine uyulmuştur. Çalışmada etik kurul izni gerekmemiştir.

\section{Yazar Katkısı ve Çıkar Çatışması Beyan Bilgisi}

Makalede 1. yazar \%60, 2. yazar \%40 katkıda bulunmuştur. Herhangi bir çıkar çatışması bulunmamaktadır.

\section{Kaynaklar}

Akpınar Külekçi E., (2018b). Erzurum'da kentsel mekanlarda kullanılan bazı kent donatı, zemin ve bitkisel elemanlarının ergonomik ve antropometrik yönden incelenmesi, ATA Planlama ve Tasarım Dergisi, (2), 35-45.

Akpınar Külekçi, E. (2018a). Kent donatı elemanlarında özgün tasarımların peyzaj ergonomisi yaklaşımıyla irdelenmesi. Mimarlık Bilimleri ve Uygulamaları Dergisi, 3(2), 29-109.

Akpınar Külekçi, E., ve Irmak, M. A. (2019). Kent Parklarında kullanılan donatı elemanlarının estetik ve fonksiyonel açıdan yeterlilikleri; Erzurum Kenti örneği. Journal of the Institute of Science and Technology, 9(2), 1144-1155.

Aksu, Ö. V. (2012). Kent mobilyaları tasarımında özgün yaklaşımlar. Inönü Üniversitesi Sanat ve Tasarım Dergisi, 2(6), 373-386.

Aykut, F. (1997). Dış Mekân Donatı Elemanlarında Ahşap Malzeme Kullanımı: Bartın Belediye Parkı Örneği, Yüksek Lisans Tezi (basılmamış), Zonguldak Karaelmas Üniversitesi, Bartın.

Bayazıt, E. (2018). Kentsel Donatı Elemanlarının Kent Kimliği ve Estetik Değerler Yönünden İncelenmesi: Trabzon ve Hükümet Caddeleri Örneği, Kahramanmaraş, Yüksek Lisans Tezi, Kahramanmaraş Sütçü İmam Üniversitesi Fen Bilimleri Enstitüsü, Kahramanmaraş.

Bayramoğlu, E. ve Özdemir, B. (2012). Trabzon kent merkezi, uzun sokak kentsel donatı elemanlarının kent kimliği açısından değerlendirilmesi. Kastamonu Üni., Orman Fakültesi Dergisi, 2012, 12(2), 182-191.

Beyhan, G., Peker, Z., Polat, E. ve Şenol, P. (2013). Kentsel / Mekansal Yaşanabilirlik Üzerine Kavramsal Bir Çözümleme. $25^{\text {Th }}$ International Building \& Life Congress, 23-28.

Bulut, Y., Atabeyoğlu, Ö. ve Yeşil, P. (2008). Erzurum kent merkezi donatı elemanlarının ergonomik özelliklerinin değerlendirilmesi üzerine bir araştırma. Tarım Bilimleri Dergisi, 14(2), 131-138

Çelikyay, S. ve Karayılmazlar, A. S. (2016). Bartın kent merkezindeki kamusal alanların kentsel ergonomi ve kent kimliği açısından incelenmesi. Bartın Orman Fakültesi Dergisi, 18(2), 224-238.

Erdoğan, E. (2006). Çevre ve kent estetiği. Bartın Orman Fakültesi Dergisi, 8(9), 68-77.

Erdönmez, E. ve Çelik, F. (2016). Kentsel mekânda kamusal alan ilişkileri. TÜBA-KED Türkiye Bilimler Akademisi Kültür Envanteri Dergisi, 14, 145-163.

Gündüz, Y. (2019). Ataköy ve Şirinevler Mahallelerindeki Kentsel Donatı Elemanlarının Kalite ve Düzeyinin; Söz Konusu İmar Bölgelerinde Yaşayan Nüfus Üzerindeki Etkisinin Araştırılması, Yüksek Lisans Tezi, İstanbul Aydın Üniversitesi Fen Bilimleri Enstitüsü, İstanbul. 
Hanifehnezhad, H. (2019). Kentsel Tasarımda Kullanıcı Algısı ve Yaşam Çevresine Aidiyeti Belirleyen Bileşenlerin Analizi: Ankara Bahçelievler Örneği, Yüksek Lisans Tezi, Gazi Üniversitesi Fen Bilimleri Enstitüsü, Ankara.

Hasol, D. (2008). Kentsel mekân ve kentlilik bilinci. http://www.doganhasol.net/kentsel-mekan-vekentlilik-bilinci-2.html

Illhan, M. E. ve Kasap, H. Ö. (2018). Sultanahmet Meydanı kent mobilyalarının estetik, işlevsellik ve algılanabilirlik ölçütlerinde kent dokusu ile uyumu. Kent Akademisi, 11(4), 508-522.

İnceoğlu, M. ve Aytuğ, A. (2009). Kentsel mekânda kalite kavramı. Megaron, 4(3).

Kaplan, A., Bayraktar, N., Tekel, A., Çalgüner, T. ve Yalçıner, Ö. (2003). Kentsel tasarım süreci ve yönetimine iliş̧in bir alan çalışması: Çeşme-Dalyan yerleşiminde yeni bir yöntem denemesi, Gazi Üniversitesi Mühendislik Mimarlık Fakültesi Dergisi, 18(2), 1-15.

Karadeniz, Z. (2019). Peyzaj Tasarım Kriterleri Açısından Samsun Kent Parklarının İncelenmesi, Yüksek Lisans Tezi, Ordu Üniversitesi Fen Bilimleri Fakültesi, Ordu.

Karahan, A. ve Sezen, I. (2019). Erzurum Kentindeki bazı önemli parkların peyzaj kalite göstergelerinin değerlendirilmesi. Nevşehir Bilim ve Teknoloji Dergisi, 8 (Enar Özel Sayı), 54-63.

Karayılmazlar, A. S. (2017). Kamusal Alanların Kentsel Ergonomi Açısından İrdelenmesi, Bartın Örneği, Yüksek Lisans Tezi, Bartın Üniversitesi Fen Bilimleri Enstitüsü, Bartın.

Kısak, E. (2021). Kentsel Mekânda Açık-Yeşil Alanların Çevre Kalitesi Açısından Değerlendirilmesi", Yüksek Lisans Tezi, Necmettin Erbakan Üniversitesi Fen Bilimleri Enstitüsü, Konya.

Kuter, N. ve Kaya, Z. (2019). Kentsel donatı elemanlarının peyzaj mimarlığı açısından değerlendirilmesi: Çankırı Örneği. Bartın Orman Fakültesi Dergisi, 21(1): 81-96.

Özgeriş, M. (2018). Kentsel donatı elemanlarının kent dokusu yönünden değerlendirilmesi: Erzurum ili örneği, AKÜ FEMÜBiD, 2018, 18, 561-574.

Perçin, M. H. (2021). Ankara Üniversitesi Ziraat Fakültesi Peyzaj Mimarlığı Bölümü Peyzaj Konstrüksiyonu 2 Ders Notlar. Erişim adresi: https://acikders.ankara.edu.tr/pluginfile.php/61576/mod_resource/content/1/14.\%20Bölüm -\%20Kentsel\%20donatı\%20elemanları.\%20.pdf

Sağlık A., Sağlık E. ve Kelkit A. (2014). Kentsel Donatı Elemanlarının Peyzaj Mimarlığı Açısından İrdelenmesi: Çanakkale Kent Merkezi Örneği, 1. Uluslararası Kentsel Planlama - Mimarlık Tasarım Kongresi, Kocaeli, Türkiye, 8-11 Mayıs 2014, ss. 1023-1035.

TUIK, (2021). TUIK Adrese dayalı nüfus kayıt sistemi. Erişim adresi: (03.10.2021) https://data.tuik.gov.tr/Bulten/Index?p=Adrese-Dayali-Nufus-Kayit-Sistemi-Sonuclari-202037210

Uşak Belediyesi, (2021). Uşak Belediyesi coğrafi yapı. Erişim adresi: https://www.usak.bel.tr/sayfa/cografiyapisi/

Yeşil, M. ve Beyli, K. N. (2018). Ordu Kenti kıyı parkları donatı elemanlarının ergonomi açısından irdelenmesi. Ordu Üniv. Bil. Tek. Derg., 8(2), 215-229.

Yıldırım, C., Erdoğan, R. ve Oktay, H. E. (2014). Antalya Kenti parklarındaki donatı elemanlarının değerlendirilmesi. Akdeniz Üniversitesi Ziraat Fakültesi Dergisi, 27(1), 13-20.

Yıldırım, E. (2004). İstanbul'da Kent Mobilyalarının Değerlendirilmesi "Sultanahmet Meydanı Örneği", Yüksek Lisans Tezi, İstanbul Teknik Üniversitesi Fen Bilimleri Enstitüsü, İstanbul. 